\title{
Does Environmental Pollution hurt Agricultural Productive Efficiency? A New Evidence using ARDL and Wavelet Coherence Approaches
}

Muhammad Ramzan ( $\nabla$ ramzanmehar7@gmail.com )

Shandong University of Finance and Economics https://orcid.org/0000-0001-7803-7960

Hafiz Arslan Iqbal

Shandong University of Finance and Economics

Tomiwa Sunday Adebayo

Cyprus International University

\section{Research Article}

Keywords: CO2 emissions, Agricultural productivity, Fertilizers, Feeds, Wavelet coherence

Posted Date: March 18th, 2021

DOl: https://doi.org/10.21203/rs.3.rs-234223/v1

License: (c) (i) This work is licensed under a Creative Commons Attribution 4.0 International License.

Read Full License 


\title{
Does Environmental Pollution hurt Agricultural Productive Efficiency? A New Evidence using ARDL and Wavelet Coherence Approaches
}

\author{
Muhammad Ramzan ${ }^{*}$, \\ 1. Shandong University of Finance and Economics, Faculty of International Economics and Trade, 250014, \\ Jinan, Shandong, China. \\ Email: ramzanmehar7@gmail.com \\ ORCID: http://orcid.org/0000-0001-7803-7960
}

*Correspondence Author

\section{Hafiz Arslan Iqbal ${ }^{1}$}

1. Shandong University of Finance and Economics, Faculty of International Economics and Trade, 250014, Jinan, Shandong, China.

Email: arslaniqbalmughal@yahoo.com

\section{Tomiwa Sunday Adebayo ${ }^{2}$}

2. Cyprus International University, Faculty of Economics and Administrative Sciences, Department of Business Administration, Nicosia, Northern Cyprus, TR-10 Mersin Turkey.

Email: twaikline@gmail.co

ORCID: http://orcid.org/0000-0003-0094-1778 


\begin{abstract}
Environmental change daunts the aptitude to ensure global food security. The greatest significant threat to world fronting is how to mitigate environmental pollution without sacrificing agricultural productivity. The sharp rise in carbon dioxide emissions and global warming is altering the agriculture productivity's patterns as its vulnerability can be sensed by farmers. The spillover impact of climatic changes predicted to be great but differs by area and crop. This research fulfills the unprecedented need of adopting robustness methods to quantify the impact of $\mathrm{CO}_{2}$ emissions, agriculture labor, land, feeds, and fertilizers on agriculture productivity over five decades-long data structured in timeseries. The fully modified ordinary least square (FMOLS), dynamic ordinary least square (DOLS), wavelet transform coherence (WTC) method, and gradual shift causality, tools have been espoused to observe the dynamic linkage in the long-term and short-run. The ARDL bound test confirms long-term co-integrated relation among the indicators. Furthermore, there is evidence of positive association between agriculture productivity and regressors which is also supported by the wavelet coherence outcomes. The Gradual shift causality test present a uni-directional causal link from all determinants to agriculture productivity which illustrates that all the regressors can significantly predict agriculture productivity. So, policies need to be formulated to explore a practical expansion approach with efficient use of fertilizers and feeds at an optimum level, in addition to environmental protection by encouraging public and private investment in agricultural research.
\end{abstract}

Keywords: $\mathrm{CO}_{2}$ emissions; Agricultural productivity; Fertilizers; Feeds; Wavelet coherence

\title{
1. Introduction
}

The current generation is facing enormous challenges by climate change that has very adverse socioeconomics and environmental impact. The whole world is witnessing unprecedented heat waves, cruel droughts, an increase in air pollution and $\mathrm{CO}_{2}$ emissions. The relentless surge in greenhouse gases like fluorinated gases, methane $\left(\mathrm{CH}_{4}\right)$, nitrous oxide $\left(\mathrm{N}_{2} \mathrm{O}\right)$, and carbon dioxide $\left(\mathrm{CO}_{2}\right)$ are affecting the pattern of rain and temperature and negatively influencing land resources and water (Alexandratos, Nikos; Bruinsma, 2012; Ali et al., 2017; Kurukulasuriya et al., 2006; Mendelsohn, 2014). All poses of these dangers are a severe threat to food security. No country has strong enough to counter these challenges in a quicker way. However, more widen impacts are touched in developing countries due to high vulnerabilities and incapacity to mitigate the threats (Parker et al., 2019). Currently, an immense challenge comes from the loss of natural environments to make room for farming. Rainfall trends around the countries have started to alter, and these shifts are expected to escalate over the next years. It means more prolonged cycles, often within the same areas, with heavy rain and more extended dry periods.

Similarly, scientific evaluation about the air quality, including pollution forecasts and future greenhouse gas sequestration, is an imperative new environmental science field that presents foremost challenges to regulatory authorities. It is becoming notoriously hard to normalize $\mathrm{CO}_{2}$ emissions of gases and specific substances from agriculture as this segment concerns the most fundamental human needs, i.e., foods. The current proposal blends preliminary research with social and political overlays, spanning a vast spectrum of practices in a dynamic sector. Pakistan being an agriculture-based economy is affected the most because of straight contact with nature, ranked $8^{\text {th }}$ in the world's primarily vulnerable country through climate change with the substantial difference in rainfall due to 2 - 
$3^{\circ}$ expected rise of temperature by 2050 (Ahmad and Afzal, 2020). For instance, tropospheric ozone $\left(\mathrm{O}_{3}\right)$ is particularly harmful to crop yields among different air pollutants. Ozone-induced crop fatalities, supposed to cost around US\$ 11.18 billion in the year 2000 (Ainsworth et al., 2012). Temperature change with negative intensity to be unfavorable for various crops (Proskurowski et al., 2008). These uncertain events prompt us with a critical resilience thought message that unpredictable climate changes cause a rapid impact on agriculture productivity. Changes in crop management can alleviate climate change's negative influence, primarily due to temperature increases on crop phenology. But the introduction of new cultivars and a longer growth cycle could significantly affect yield phenology and potentially increase under a warming trend (Abbas et al., 2017).

Experts have given more alternative methods to ease the procedures to obtain technological advancement and foreign direct investment (Ahmad et al., 2020). It is hard for mainly developing nations to adopt unconventional methods with financial and high-tech constraints. However, emerging countries are the ones that have a high economic dependency on agriculture production, such as Pakistan, India, and Bangladesh in South Asia. Although Pakistan is still selfsufficient presently in major staples - ranked $8^{\text {th }}$ in wheat production, $5^{\text {th }}$ in sugarcane, $10^{\text {th }}$ in rice, and $4^{\text {th }}$ in milk (UNICEF, 2018). In contrast, moving towards urbanization is a vast threat to a rise in population, an enormous number of cutting trees, and overcrowded places that negatively impact Pakistan's ecosystem. All these led to rising floods, soil erosion, air pollution, and greenhouse gases in the environment (Kousar and Shabbir, 2021).

The possible impacts are less pronounced; however, food and hunger insecurity in different areas are caused by climate change (Wheeler and Braun, 2013). Previous studies have established that this sector permits the development of various non-agriculture industries and may have a hostile effect on crop yields with climate change (Lobell et al., 2015). The link between environmental change and agricultural productivity is a meaningful area for researchers to assess for developing countries (Anjum, Zada, and Tareen, 2016). Though the requirement to determine this topic is exceptional as in the worst case, if the agricultural productivity does not equal the food demand, it might lead to costly buying and raise the rate of poverty and hunger worldwide (Ahmad et al., 2016; Godfray et al., 2010; Foley et al., 2013; Lashkari et al., 2012). Therefore, this research examines the impact of $\mathrm{CO}_{2}$ emissions, agriculture labor, land, feeds, and fertilizers on Pakistan's agriculture productivity using data from 1961 to 2016. The robustness of methods portrays the high efficiency of results while examining the lag phase and coherence between time series function of frequency and time. The current study is different from the prior research by employing the novel wavelet coherence test. Some essential properties of the wavelet transform coherence: like capable of analyzing signals with functionality that differ over time, offers illustration on a diverse scale, and conveniently obtainable via filter bank. The literaturebased knowledge indicates that not a single researcher had applied the wavelet coherence approach to analyze environmental data to enumerate agriculture productivity. The advantage of the wavelet coherence tests is that it can capture both correlation and causal linkage between series at different frequencies and time periods. Thus, the present study fills the gap in the ongoing literature. The practice of finding an intense relationship between climate change, $\mathrm{CO}_{2}$ emission, and productivity in agriculture development presents new evidence both in tabular and visual forms. Besides the introductory part, the below portion of this research consists and organized as follows: a review of relevant studies section provides the particular literature and systematic review in tabular form. Data \& methods section 
contains a new approach series of methodology while finding \& discussion parts present the outcomes in detail. Finally, the conclusion \& policy implications fall in the last section.

\section{Review of Relevant Studies}

In terms of labor contribution, agriculture remains Pakistan's most important sector of the economy, and as such, the mainstream of the population relies directly or indirectly on it. The main crops like rice, wheat, maize, cotton, and sugarcane account for $21.73 \%$ in the agriculture sector and contributing $4.20 \%$ in GDP, while $11.53 \%$ accounts for other crops with a $2.23 \%$ share in GDP (Pakistan, 2020). Stages of crops guided by the prevailing weather conditions and reflected in the accumulation of rising degree days influence the field management methods, including selecting crops and improvements in sowing dates (Ahmad et al., 2017; Wajiha and Qadir, 2016).

Higher temperatures in the growing season may have a major effect on agricultural production and food security (DS and RL., 2009). Pakistan's climate is ideal for cultivating different crops, such as cotton, wheat, rice, corn, and sugar cane. Above all, the wheat crop is the primary due to high domestic demand and consumption (Dharmasiri, 2012). The synergies between environmental concerns and agriculture productivity are highlighted by various authors (Aragón et al., 2019; Di Gregorio et al., 2017; Liang et al., 2017; Ukhurebor et al., 2021). The impact of business activities involves industrial production that pollutes the air, water, and various crops. The examination of the impact of air pollution of industries on farming crops includes recognizing the roles of the dose-response between the accumulation of contaminants and the loss of agriculture. Multiple studies have quantified the dose-response, and some applied the method of field experiments.

Consequently, some authors stated the relationship between total factor productivity of agriculture and air pollution (Zhou et al., 2018). Air pollution diminishes labor productivity from the economic side, leading to disrupting some certain degree of productivity of yield's physiological and biochemical, instigating the nutrient attention in acid rain and soil degradation (Heck et al., 1988; Zivin and Neidell, 2018). Parker (2015) claimed that financial considerations are beneficial in mitigating national environmental issues. Rafindadi (2014) evaluated the relations in Asia-Pacific countries between $\mathrm{CO}_{2}$ pollution, water supplies, and natural resources and concluded; those variables influence the country-wide environmental sustainability plan. Another author used the ARDL bounds test to determine the climate change impact on food crops from 1968 to 2014. The finding revealed $\mathrm{CO}_{2}$ emission and land area negatively effecting cereal yield while average rainfall, energy consumption, and labor force have a positive impact on Turkey's production (Chandio et al., 2020). Schmidhuber (2007) proposed that climate change would directly affect economic growth, food supply, and prices after finding a strong relationship between $\mathrm{CO}_{2}$ emission and crop yield. Likewise, several studies have been carried out on climate change and agriculture productivity for developing nations, particularly in agriculture-based economy, from the exhaustive evaluation on the implementation of econometrics in agriculture and environmental economics (Fan and Carroll, 2012; Ozturk, 2015; Rehman et al., 2019). For the audience's ease, an indepth systematic review of additional literature has comprised in tabular form as follows. 
Table 1. Systematic Review

\begin{tabular}{|c|c|c|c|c|}
\hline Authors & Aims & Country/Region & Data \& Methods & Conclusion \\
\hline $\begin{array}{l}\text { Warsame et al. } \\
\text { (2021) }\end{array}$ & $\begin{array}{l}\text { Ascertain the measure the } \\
\text { impression of, measured } \\
\text { rainfall, temperature, climate } \\
\text { change, and } \mathrm{CO}_{2} \text { on crop } \\
\text { production }\end{array}$ & Somalia & $\begin{array}{l}\text { Time Series (1985 } \\
\text { to 2016) } \\
\text { ARDL bounds, } \\
\text { Granger causality }\end{array}$ & $\begin{array}{l}\text { The rise of crop production in the long } \\
\text { run by rainfall during the decline in } \\
\text { the short-run. No significant impact } \\
\text { has found of } \mathrm{CO} 2 \text { on crop production }\end{array}$ \\
\hline Aziz et al. (2020) & $\begin{array}{l}\text { To evaluates the EKC } \\
\text { between economic growth, } \\
\text { forest area, agriculture } \\
\text { production, renewable } \\
\text { energy, and environmental } \\
\text { degradation }\end{array}$ & Pakistan & $\begin{array}{l}\text { Time Series (1990 } \\
\text { to 2018) } \\
\text { QARDL } \\
\text { methodology }\end{array}$ & $\begin{array}{l}\text { The short-run impact of agricultural } \\
\text { production on Ecological footprints } \\
\text { demonstrate statistically negative } \\
\text { results }\end{array}$ \\
\hline $\begin{array}{l}\text { Koondhar et al. } \\
\qquad(2020)\end{array}$ & $\begin{array}{l}\text { To explore the link between } \\
\text { energy consumption, air } \\
\text { pollution, and the } \\
\text { involvement of agriculture in } \\
\text { GDP. }\end{array}$ & China & $\begin{array}{l}\text { Time series } \\
(1998-2018) \\
\text { ARDL bounds } \\
\text { model, CUSUM, } \\
\text { and CUSUMSQ } \\
\text { test. }\end{array}$ & $\begin{array}{l}\text { A casual affiliation was found } \\
\text { between air pollution and agriculture } \\
\text { development. The exponential } \\
\text { population growth has led to a slow } \\
\text { reduction in capital to gratify the } \\
\text { rising population's food need. }\end{array}$ \\
\hline Rashid et al. (2020) & $\begin{array}{l}\text { To inspect the influence on } \\
\text { cotton productivity by } \\
\text { climatic variations }\end{array}$ & Pakistan & $\begin{array}{l}\text { Time Series } \\
(1981-2015) \\
\text { ARDL bounds } \\
\text { testing }\end{array}$ & $\begin{array}{l}\text { All determinants of climate have a } \\
\text { substantial effect on cotton } \\
\text { productivity. Whereas, All climate } \\
\text { variables have a positive impact on } \\
\text { crop productivity except temperature. }\end{array}$ \\
\hline $\begin{array}{l}\text { Sharmila Raisa et al. } \\
\qquad(2020)\end{array}$ & $\begin{array}{l}\text { To observe the nexus } \\
\text { between agricultural output, } \\
\text { air quality, consumption of } \\
\text { fertilizer, and agriculture } \\
\text { contribution to the domestic } \\
\text { economy }\end{array}$ & Bangladesh & $\begin{array}{l}\text { Time Series (1972 } \\
\text { to 2019) } \\
\text { ARDL model }\end{array}$ & $\begin{array}{l}\text { A close correlation exists between air } \\
\text { pollution and farm productivity, } \\
\text { agricultural land usage, energy use, } \\
\text { fertilizer use, and crop production. }\end{array}$ \\
\hline Sharif et al. (2020) & $\begin{array}{l}\text { To influentially investigate } \\
\text { economic growth, transport, } \\
\text { and tourism on } \mathrm{CO} 2 \\
\text { emissions. }\end{array}$ & Malaysia & $\begin{array}{lr}\text { Time } & \text { Series } \\
(1995 Q 1 \quad \text { to } \\
\text { 2018Q4) } \\
\text { QARDL Model }\end{array}$ & $\begin{array}{l}\text { Economic development, transport, } \\
\text { and globalization with } \mathrm{CO} 2 \text { are } \\
\text { substantially positive, and tourism } \\
\text { indicates a negative relationship. }\end{array}$ \\
\hline Mehmood (2020) & $\begin{array}{l}\text { To measure the relationship } \\
\text { between } \mathrm{CO} 2 \text { emission and } \\
\text { globalization }\end{array}$ & Singapore & $\begin{array}{l}\text { Time Series } \\
(1970-2014) \\
\text { ARDL approach }\end{array}$ & $\begin{array}{l}\text { Growing political globalization by } \\
1 \% \text { would increase pollution by } \\
2.06 \% \text { in the long run. The presence }\end{array}$ \\
\hline
\end{tabular}




$\begin{array}{ll}\text { Naseem et al. (2020) } & \text { To determine the } \\ & \text { asymmetrical effect of } \\ & \text { agriculture, food security, } \\ & \text { and fossil fuel consumption } \\ & \text { on } \mathrm{CO} 2 \text { emission }\end{array}$

Ali et al. (2020) To investigate the causal link between $\mathrm{CO} 2, \mathrm{CO} 2 \mathrm{~S}$, energy consumption (EU), (FOF), (GDP), and net domestic credit (NDC).

Burakov (2019) To empirically review the relationship between $\mathrm{CO} 2$ emissions and determinants, mainly for agriculture.

Khan et al. (2019)

aim to report the asymmetrical effects of environmental regulation on $\mathrm{CO} 2$ emission

Shoko et al. (2019) Investigate whether the newly changing possibility of climate variability affects the maize yield

Gokmenoglu et al. To empirically measure the (2019) relation among $\mathrm{CO}_{2}$
Pakistan

Time Series (1969 to 2018)

Multiple-unit root (PP, KPSS, ADF, and Z\&A).

Asymmetrical

ARDL correlation

Time Series (1971

to 2014)

ARDL bound testing, $\mathrm{ADF}$, and PP.

Russia

Time (1990-2016)

ARDL bound test and pairwise granger causality.

Time Series

(1991-2015)

Non-linear ARDL

to 2016)

ARDL

Time emissions, consumption, and agriculture with the existence of EKC.

China ARDL.
Time Series (1970

of environmental Kuznets curve exist in Singapore

The findings confirmed the adverse shocks, the atypical reaction of $\mathrm{CO} 2$ to agricultural value-added. Also, consumption of fossil fuels would further exacerbate environmental conditions

Outcome presents $\mathrm{CO}_{2} \mathrm{~S}, \mathrm{EU}$, and GDP have a significant bonding with $\mathrm{CO}_{2}$ emissions while NDC and FOF are not substantial.

Existence of long-run relationship between $\mathrm{CO} 2$ emission and agriculture found. The statistical role of Environmental pollution has a small impact on agriculture yet. Moreover, it revealed uni-directional causality from agriculture production to $\mathrm{CO} 2$ emissions

Environmental regulations, Financial development are advantageous and decline the $\mathrm{CO} 2$ emission while growth in urban population enhanced.

Rainfall and temperature were found as essential factors of maize yield. Nevertheless, excessiveness could have the opposite effect.

Series Conclusion discloses the positive and (1971-2014) significant results for energy Bounds test consumption, real income. approach under Agricultural development positively results with elastic impact while inelastic on $\mathrm{CO} 2$ emission as real 


\begin{tabular}{|c|c|c|c|c|}
\hline Matthew et al. (2018) & $\begin{array}{l}\text { To evaluate the long term } \\
\text { impact of greenhouse gas } \\
\text { emission on health outcomes }\end{array}$ & Nigeria & $\begin{array}{l}\text { Time Series } \\
(1985-2016) \\
\text { ARDL }\end{array}$ & $\begin{array}{l}\text { A } 1 \% \text { increase in GHGE may cut life } \\
\text { hope by } 0.0422 \% \text {. In case this } \\
\text { happens, the rate of mortality would } \\
\text { be } 146.6 \% \text {. }\end{array}$ \\
\hline Husnain et al. (2018) & $\begin{array}{l}\text { Climate change impact on } \\
\text { agriculture value-added are } \\
\text { examined }\end{array}$ & 60 Countries & $\begin{array}{l}\text { Panel data (1999 } \\
\text { to 2011) } \\
\text { GEMs, IAMs, } \\
\text { production } \\
\text { function models }\end{array}$ & $\begin{array}{l}\text { A positive linkage of precipitation has } \\
\text { shown up with agriculture. However, } \\
\text { the temperature has a negative } \\
\text { association with Agriculture. }\end{array}$ \\
\hline Mahrous (2018) & $\begin{array}{l}\text { Explore the relationship } \\
\text { between global climate } \\
\text { change and the production of } \\
\text { cereals. }\end{array}$ & Egypt & $\begin{array}{l}\text { Time Series } \\
(1971-2013) \\
\text { ARDL Approach }\end{array}$ & $\begin{array}{l}\text { The adverse effect has calculated on } \\
\text { cereal crop in the short-run from } \\
\text { temperature and rainfall } \\
\text { While in the long-run, some crop's } \\
\text { yield might be beneficial in case of } \\
\mathrm{CO} 2 \text { increases. }\end{array}$ \\
\hline $\begin{array}{l}\text { Asumadu-Sarkodie } \\
\text { and Owusu (2016) }\end{array}$ & $\begin{array}{l}\text { To investigate the long-run } \\
\text { causal relationship between } \\
\mathrm{CO}_{2} \text { emissions and the } \\
\text { agricultural development }\end{array}$ & Ghana & $\begin{array}{l}\text { Time series (1961 } \\
\text { to 2012) } \\
\text { ARDL, VECM }\end{array}$ & $\begin{array}{l}\text { Confirmation of a long-run } \\
\text { relationship depicts from results and } \\
\mathrm{CO}_{2} \text { emission found to negatively } \\
\text { affect coarse grain, bean, vegetable, } \\
\text { livestock, and cocoa. }\end{array}$ \\
\hline
\end{tabular}

income shows negative and inelastic air pollution.

Note: ADF-augmented dickey fuller, PP-Phillips Perron, KPSS-Kwiatkowski-Phillips-Schmidt-Shin, ARDL- Autoregressive distributed lag, QARDL-Quantile autoregressive distributive lag, VECM-vector error correction model, GEM-general equilibrium model, IAM-integrated assessment model.

Most of the studies have examined the nexus of climate change and agricultural productivity through ARDL for developing countries recently, adding more (Ahsan et al., 2020; Attiaoui and Boufateh, 2019; Banday and Aneja, 2019; Janjua et al., 2014). As with the world's growing population, it is vital to accelerate agricultural production to match the essentials nutrition to feed the world (Weeks, 2015). However, many climatic and environmental issues, including air pollution, rapid climate change, and ecological degradation, affect agricultural productivity. It is indispensable to identify the in-depth dynamics relationship of these factors with agricultural productivity to provide food security and meet Pakistan's future food demand. To the best of comprehension, earlier studies have provided only simple relational evidence among certain factors and used numeric techniques to capture relations differently with frequencies and periods such as simple regression, ARDL, FMOL, and more. However, there has been no sign from existing literature demonstrating a dynamic linkage between climate change, $\mathrm{CO}_{2}$ emissions, and agricultural productivity using the wavelet coherence technique. The wavelet method of analysis gives an in-depth association of 
determinants within the timescale and frequency bands (Pla et al., 2020). The wavelet efficiency becomes an upsurge when it comes to interacting lead-lag relationship on time series used in non-linear; it simultaneously allows to measure the dynamic linkages and causality (Adebayo and Akinsola, 2020). Thus, the wavelet coherence technique takes into account break-in time series, and it could otherwise disrupt measurement parameters without considering it (Kirikkaleli and Gokmenoglu, 2020).

\section{Materials and Methods}

\subsection{The conceptual underpinnings}

This portion emphasizes the connotation and the climatic impact on agriculture productivity. According to think-tank German watch on global climate index report, Pakistan ranked $5^{\text {th }}$ most vulnerable globally, vanished 9989 lives, $\$ 3.8$ billion economic suffering, and perceived 152 extreme weather events between 1999 to 2018 (Eckstein et al., 2020). However, these large scale effects have been remained and continue under great debate.

\subsection{Data and Assessment Scheme}

This article uses a time series yearly data of TFP and $\mathrm{CO}_{2}$ emission, Agri-Land, Agri-Labor, Fertilizers, and Feeds spanning from 1961 to 2016 of Pakistan. The TFP is the dependent variable in the model, and the independent variables are $\mathrm{CO}_{2}$ emission, Agri-Land, Agri-Labor, Fertilizers, and Feeds. The natural logarithm of the series has been taken to ensure the normality conforms. Table 2 depicts the source, unit, and description of the determinants. The study analysis flow is depicted in Figure 1. The economic function and econometric model are highlights in equations 1 and 2 as follows;

$$
\begin{aligned}
& T F P_{t}=f\left(A L B_{t}, A L D_{t}, F D_{t}, C O_{2 t} F T_{t}\right) \\
& T F P_{t}=\vartheta_{0}+\vartheta_{1} A L B_{t}+\vartheta_{2} A L D_{t}+\vartheta_{3} F D_{t}+\vartheta_{4} C O_{2 t}+\vartheta_{4} F T_{t}+\varepsilon_{t}
\end{aligned}
$$

In Equation 2, TFP denotes total factor productivity of agriculture that reflects agricultural efficiency; ALB, ALD, $\mathrm{FD}, \mathrm{FT}$, and $\mathrm{CO}_{2}$ signifies agricultural labor, land, feed, fertilizer, and carbon dioxide emissions, respectively.

\begin{tabular}{|c|c|c|c|c|}
\hline Symbol & Log-Symbol & Description & Units & Sources \\
\hline TFP & LnTFP & Total agricultural factors productivity & Index & USDA \\
\hline FD & LnFD & $\begin{array}{l}\text { Sum of all sources of metabolizable energy } \\
\text { (ME) used agricultural feeds }\end{array}$ & 1000 Megacalories & USDA \\
\hline FT & LnFT & $\begin{array}{c}\text { Sum of } \mathrm{N}, \mathrm{P}_{2} \mathrm{O}_{5} \text {, and } \mathrm{K}_{2} \mathrm{O} \text { fertilizers } \\
\text { consumption. }\end{array}$ & Metric tons & USDA \\
\hline ALB & LnALB & $\begin{array}{c}\text { Total numbers of adults economically in } \\
\text { agricultural activities }\end{array}$ & 1000 persons & USDA \\
\hline ALD & LnALD & $\begin{array}{c}\text { Sum of rainfed cropland, irrigated cropland } \\
\text { and permanent pasture area }\end{array}$ & 1000 hectares & USDA \\
\hline $\mathrm{CO}_{2}$ & $\mathrm{LnCO}_{2}$ & Carbon dioxide emission & Mt. tons per capita & WDI \\
\hline
\end{tabular}

Table 2. Variables, Units and Sources 
*USDA- United States Department of Agriculture, **WDI- World Development Indicators

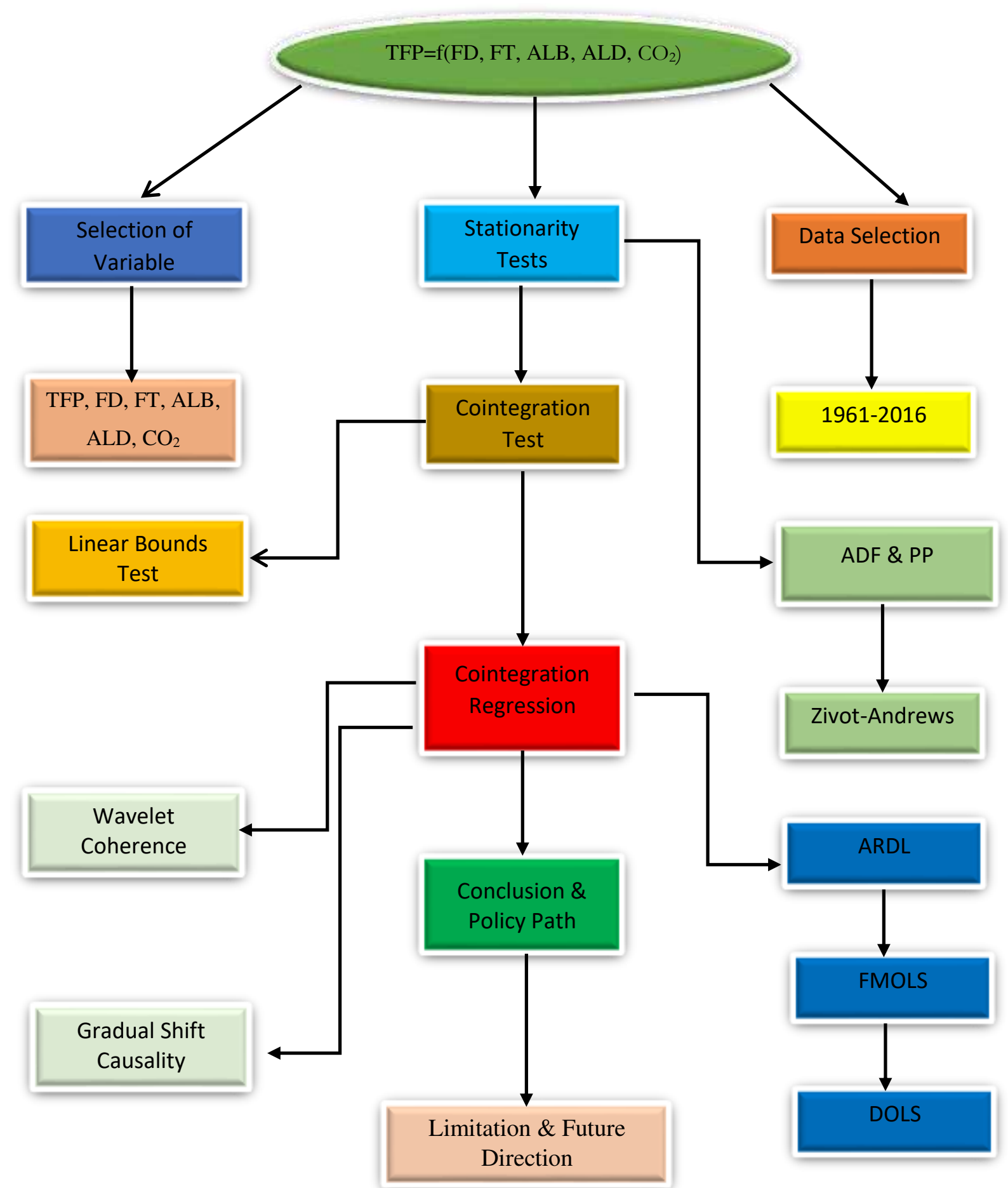

Figure 1. Flow Chart 


\subsection{Econometric Tools}

\subsubsection{Unit root tests}

It is imperative to investigate series stationarity features before conducting further analysis. Thus the present research utilized conventional unit root tests (ADF and PP). The sensitivity to serial correlation in error terms and heteroscedasticity is the main distinction between ADF and PP tests. The Equations of ADF and PP explain as below;

ADF test:

$$
\Delta Y_{t}=\beta^{\prime} D_{t}+\pi Y_{t-1}+\sum_{j-1}^{p} \sigma_{j} \Delta Y_{t-j}+\varepsilon_{t}
$$

Whereby $D_{t}$ depicts the deterministic term vector while the error term is represented by $\varepsilon_{t}$.

PP test:

$$
\Delta Y_{t}=\beta^{\prime} D_{t}+\pi Y_{t-1}+\mu_{t}
$$

The serial correlation and heteroscedasticity in the error terms are disregard in the PP test

As stated by Adebayo (2020), Kirikaleli \& Adebayo (2020), and Alola et al. (2019), the conventional unitroot tests may present disingenuous outcomes if there is evidence of structural break(s) in series. Thus, the present study utilized Zivot \& Andrews (ZA) unit root test introduced by Zivot to capture both stationarity features and a single break in series. The Equation of ZA exemplifies as follows:

Model 1: $\Delta x_{t}=\varphi+\varphi x_{t-1}+\pi t+\delta D U_{t}+\sum_{j=1}^{k} d_{j} \Delta x_{t-j}+\mu_{t}$,

Model 2: $\Delta x_{t}=\varphi+\varphi x_{t-1}+\pi t+\gamma D T_{t}+\sum_{j=1}^{k} d_{j} \Delta x_{t-j}+\mu_{t}$,

Model 3: $\Delta x_{t}=\beta+\beta x_{t-1}+\beta t+\theta D U_{t}+\theta D T_{t}+\sum_{j=1}^{k} d_{j} \Delta x_{t-j}+\mu_{t}$

Where $D U_{t}$ depict dummy variable for mean shift occurring at each possible break-date (TB) while $D T_{t}$ is the respective trend shift variable. Formally,

$$
D U_{t}=\left\{\begin{array}{l}
1 \ldots \text { if } t>T B \\
0 \ldots \text { if } t<T B
\end{array} \text { and } D T_{t}=\left\{\begin{array}{l}
t-T B \ldots \text { if } t>T B \\
0 \ldots . \quad \text { if } t<T B
\end{array}\right.\right.
$$

\subsubsection{ARDL Approach}

Auto-Regressive Distribution Lag Model (ARDL) developed by Pesaran and Shin (1998) and Pesaran et. al (2001) was used to capture the long-run co-integration association between the dependent and independent variables. Benefits of the ARDL bounds test over the other conventional or traditional co-integration techniques areas: (i) it can be used when there is a mixed order of integration; (ii) it incorporates both the short and long-run coefficients simultaneously; (iii) it is perfectly fit for small sample size; (iv) accommodating different lag length; (v) autocorrelation problem is removed. The calculated F-statistics are being compared to the lower and upper bound critical values. When the calculated F-statistics is below, the null hypothesis is not rejected; when the calculated F- 
statistics is greater, the null hypothesis is rejected, which shows evidence of a long-run relationship among the variable. Equation (7) below explains the ARDL bounds model;

$$
\begin{aligned}
\Delta T P F_{t}=\theta_{0}+ & \sum_{i=1}^{t} \theta_{1} \Delta T P F_{t-1}+\sum_{i=1}^{t} \theta_{2} \Delta A L B_{t-i}+\sum_{i=1}^{t} \theta_{3} \Delta A L D_{t-i}+\sum_{i=1}^{t} \theta_{4} \Delta C O_{2 t-i}+\sum_{i=1}^{t} \theta_{5} \Delta F D_{t-i} \\
& +\sum_{i=1}^{t} \theta_{6} \Delta F T_{t-i}+\beta_{1} T P F_{t-1}+\beta_{2} A L B_{t-1}+\beta_{3} C O_{2 t-1}+\beta_{4} F D_{t-1}+\beta_{6} F T_{t-1} \\
& +\varepsilon_{t}
\end{aligned}
$$

The null hypothesis and the alternative hypotheses are no co-integration and evidence of co-integration, respectively. We fail to accept the null hypothesis if the F-statistics is more than the lower and upper bond critical values. The alternative and null hypothesis are illustrated by Equations 8 and 9 correspondingly;

$$
\begin{aligned}
& H_{0}=\vartheta_{1}=\vartheta_{2}=\vartheta_{3}=\vartheta_{4}=\vartheta_{5}=\vartheta_{6} \\
& H_{a} \neq \vartheta_{1} \neq \vartheta_{2} \neq \vartheta_{3} \neq \vartheta_{4} \neq \vartheta_{5} \neq \vartheta_{6}
\end{aligned}
$$

Where $H_{0}$ denotes the null hypothesis and $H_{a}$ illustrates the alternative hypothesis.

After the long-run relationship is established, the ARDL model derives the error correction model (ECM). It was derived by estimating the model's short-run parameters by applying ECM. Hence, incorporating the ECM model into our short-run parameter of the ARDL model would result in Equation 10 as:

$$
\begin{gathered}
\Delta T P F_{t}=\theta_{0}+\sum_{i=1}^{t} \theta_{1} \Delta T P F_{t-1}+\sum_{i=1}^{t} \theta_{2} \Delta A L B_{t-i}+\sum_{i=1}^{t} \theta_{3} \Delta A L D_{t-i}+\sum_{i=1}^{t} \theta_{4} \Delta C O_{2 t-i}+\sum_{i=1}^{t} \theta_{5} \Delta F D_{t-i} \\
+\sum_{i=1}^{t} \theta_{6} \Delta F T_{t-i}+\beta_{1} T P F_{t-1}+\beta_{2} A L B_{t-1}+\beta_{3} C O_{2 t-1}+\beta_{4} F D_{t-1}+\beta_{6} F T_{t-1}+\omega E C T_{t-i} \\
+\varepsilon_{t}
\end{gathered}
$$

Where: $\theta_{\mathrm{i}=5}$ denote coefficients in the short run, $\varepsilon_{\mathrm{t}}$ represents the error term, $\beta_{\mathrm{i}=5}$ mean coefficients, in the long run, $t$ denotes the lags lengths, $\mathrm{ECT}_{\mathrm{t}-\mathrm{i}}$ denotes error correction term. It is showing the speed of adjustment from a shortrun shock to the long-run equilibrium. $\omega$ represents ECM coefficients, which will be negative and significant.

\subsubsection{Wavelet Approach}

The wavelet approach is utilized in the current research to gather information about the time-frequency dependency between TFP and $\mathrm{CO}_{2}$ emission, agri-land, agri-labor, fertilizers, and feeds in Pakistan using yearly data spanning from 1961 to 2016. Goupillaud et al. (1984) initiated the Morlet family. It is accepted that when time series variables are estimated and not stationary, the result will yield bias estimates if the conventional time-domain method is not employed. Additionally, in economics and finance, time-series data are prone to break (s); hence the traditional test of causality outcomes with parameters fixed are susceptible to surface (Adebayo and Odugbesan, 2020). Contrary to time-domain causality, the standalone frequency domain method major concern, also known as Fourier transform. 
Therefore, to abolish these issues in the estimations, the wavelet coherence technique is utilized in this research. Morlet wavelet equation is presented below;

$$
\varpi(t) \pi^{-\frac{1}{4}} e^{-i \varpi t} e^{-\frac{1}{2} t^{2}}
$$

where:, $w$ is utilised on time series frequency that is limited; $\mathrm{p}(t), n=0,1,2,3 \ldots . \mathrm{N}-1$; i is $\sqrt{-1}$. The time series is transmuted into the time-frequency domain and transmits to the change of wavelets. $\varpi$ Is converted and developing into $\varpi_{k, f}$. This formula can be seen below:

$$
\varpi_{k, f}(t)=\frac{1}{\sqrt{h}} \varpi\left(\frac{t-k}{f}\right), k, f \in \mathbb{R}, f \neq 0
$$

Where: $k$ describes the time and place of whereas $f$ denotes the frequency. Odugbesan and Adebayo (2020) stated that $\mathrm{k}$ and $\mathrm{f}$ are the main parameters in the wavelet approach. The CWT Equation is depicted as follows:

$$
\varpi_{p}(k, f)=\int_{-\infty}^{\infty} p(t) \frac{1}{\sqrt{f}} \varpi\left(\overline{\frac{t-k}{f}}\right) i d s,
$$

The revitalization of the time series variable $\mathrm{p}(\mathrm{t})$ is depicted by the next equation and the coefficient $w$.

$$
p(t)=\frac{1}{C_{\varpi}} \int_{0}^{\infty}\left[\int_{-\infty}^{\infty}\left|\mathfrak{w}_{p}(a, b)\right|^{2} d a\right]
$$

The wavelet power spectrum (WPS) captures the time series of vulnerability. The wavelet power spectrum equation is summarized below;

$$
W P S_{p}(k,)|\quad F W P(k, f)|^{2}
$$

The time series cross wavelet transform (CWT) as follows:

$$
W(\text { ork }, f)=W_{p}(k, f) \overline{W_{q}(k, f)}
$$

The CWT of TFP and $\mathrm{CO}_{2}$ emission, agri-land, agri-labor, agri-machinery, fertilizers, and feeds in Pakistan using yearly data spanning from 1961 to 2016 parameters are depicted by $\mathrm{Wp}(\mathrm{k}, \mathrm{f})$ and $\mathrm{Wq}(\mathrm{k}, \mathrm{f})$ correspondingly. The wavelet coherence square is illustrated by Equation 7:

$$
R^{2}(k, f)=\frac{\left|S\left(f^{-1} W_{p q}(k, f)\right)\right|^{2}}{S\left(f^{-1}\left|W_{p}(k, f)\right|^{2}\right) S\left(f^{-1}\left|W_{q}(k, f)\right|^{2}\right)}
$$

The $R^{2}(k, f)$ reveals the intensity of the interaction without including the nature of this connection being recommended. Torrence and Compo (1998) initiated a suggestion of associated direction by wavering the two-time series by signifying deferrals. Equation 8 depicts the Phase difference:

$$
\phi_{p q}(k, f)=\tan ^{-1}\left(\frac{\mathrm{L}\left\{S\left(f^{-1} W_{p j}(k, f)\right)\right\}}{O\left\{S\left(f^{-1} W_{p j}(k, f)\right)\right\}}\right)
$$

Where, $\mathrm{O}$ is the real component operator, while $\mathrm{L}$ is the imaginary operator.

\subsubsection{Gradual Shift Causality}


Toda and Yamamoto (1995) established a framework, which is anchored on vector autoregressive (VAR) built by Sims (1980). In calculating the optimal lag length, $p+d_{\max }$ is added to the lag of $d_{\max }$, which is ascertained by the series maximum order of integration in the VAR framework. However, ignoring the structural shifts can cause the VAR model to be unreliable and contradictory (Enders and Jones, 2016; Figueiredo et al., 2012). To examine the causal linkage between TPF and $\mathrm{CO}_{2}$ emission, agri-land, agri-labor, agri-machinery, fertilizers, and feeds, Nazlioglu (2016) developed the Gradual shift causality test, which captures the structural shifts in Granger causality analysis and including the gradual and smooth shift. It can also be called the "gradual-shift causality test." The Fourier Granger causality test was developed using single-frequency (SF) and cumulative frequencies (CF), respectively, known as Fourier approximation. The modified Wald test statistic (MWALT) is generated by adding the TY-VAR analysis and Fourier approximation.

\section{Findings and Discussions}

Table 3 provides an introductory summary of all the variables used in this study. In the context of skewness and kurtosis tests, all the listed variables are approving to normal distributed, which confirms the normality assumption of the classical regression model. The probability value of the Jarque-Bera test is the standard test to measure. It reveals that all included variables are normally distributed, excluding total factor productivity of agriculture.

Table 3. Summary Statistics

\begin{tabular}{ccccccc}
\hline & ALD & ALB & FD & $\mathrm{CO}_{2}$ & FT & TFP \\
\hline Mean & 63588.7 & 15041.1 & 13091488 & 0.6032 & 1932604 & 83.879 \\
Median & 64029.4 & 13333.4 & 11491535 & 0.5787 & 1833350 & 85.965 \\
Max & 72392.0 & 27299.0 & 29017578 & 0.9878 & 5040100 & 107.18 \\
Min & 52443.0 & 7800.81 & 3184831 & 0.3083 & 41200 & 55.984 \\
Std. Dev. & 5729.4 & 5694.15 & 7892547 & 0.2220 & 1441110 & 16.474 \\
Skewness & -0.1798 & 0.65699 & 0.4623 & 0.2657 & 0.2848 & -0.1256 \\
Kurtosis & 1.9057 & 2.2365 & 1.9071 & 1.6208 & 1.8278 & 1.3798 \\
JB & 3.0960 & 5.3887 & 4.7814 & 5.0975 & 3.9632 & 6.2722 \\
Prob & 0.2126 & 0.0675 & 0.0915 & 0.0781 & 0.1378 & 0.0434 \\
\hline
\end{tabular}

In the first step, we grasp integrating the time series variables for this study. For this purpose, two traditional stationarity tests, such as ADF (Elliott et al., 1996) and PP (Phillips and Perron, 1988) have been utilized. The results of these unit root tests imitate in Table 4. The ADF test results show no static variable at the level, and only one variable is named total factor of agricultural productivity stationary at the first difference, i.e., I (I). Likewise, the PP test reveals that only agricultural land is stationary at the level, and $\mathrm{CO} 2$ is found to be stationary at the first difference, i.e., I (I).

Further, we examined the ZA unit root test by considering the structural break of time to prevent us from the misleading results of traditional unit root tests. The findings of the ZA unit root test listed in Table 5. The findings 
expose that only agricultural land stationary at level, i.e., I (0). However, all the named variables have proved to be stationary after taking the first difference, i.e., I (I). In the context of the unit root test, the literature has reported that when we found a mixture of variables' integration, it is crucial to test long-term and short-run associations using the ARDL approach (Rehman et al., 2019).

Table 4. Conventional Unit Root Test

\begin{tabular}{ccccc}
\hline & \multicolumn{2}{c}{ ADF } & \multicolumn{2}{c}{ PP } \\
\hline ALD & I $(0)$ & $\mathrm{I}(1)$ & $\mathrm{I}(0)$ & $\mathrm{I}(1)$ \\
ALB & -1.182685 & -6.390745 & $-3.646136^{* *}$ & -11.37973 \\
CO2 & -0.9617 & $-6.1419^{*}$ & -1.0193 & -6.371459 \\
FD & -1.649877 & --6.371325 & -1.943352 & $-11.257^{*}$ \\
FT & -2.472408 & -9.905282 & -2.260468 & -14.80907 \\
TFP & -2.597811 & -7.917391 & -1.450333 & -11.80757 \\
\hline
\end{tabular}

Note: Significance level of $1 \%, 5 \%$ and $10 \%$ is depicted by $* * *$ and $* * *$

Table 5: ZA Unit root Test

\begin{tabular}{ccccc}
\hline & \multicolumn{2}{c}{ At Level I $(0)$} & \multicolumn{2}{c}{ First Difference I(1) } \\
\cline { 2 - 5 } & Intercept \& Trend & Break-Date & Intercept \& Trend & Break-Date \\
\hline ALD & $-5.306^{* *}$ & 1980 & $-7.570^{*}$ & 1982 \\
ALB & -3.970 & 1985 & $-8.385^{* *}$ & 1985 \\
CO2 & 3.611 & 1980 & $-9.253^{*}$ & 1973 \\
FD & -4.368 & 1991 & $-5.412^{* *}$ & 1988 \\
FT & -3.850 & 1977 & $-9.256^{*}$ & 1984 \\
TFP & -3.830 & 1986 & $-5.279^{* *}$ & 1992 \\
\hline
\end{tabular}

Note: Significance level of $1 \%, 5 \%$, and $10 \%$ are depicted by $*$ and $* *$

Table 6 lists the ARDL bounds test findings to co-integration at the 10\%,5\%, and $1 \%$ significance levels. This model is used to measure the long-run equilibrium and the linkage between incorporated variables. The ARDL Bounds Test F-statistics has a value of 6.11 that reveals the long-run co-integration association between total agricultural factor productivity, $\mathrm{CO}_{2}$ emissions, farmland and labor, fertilizer, and feed at the significance level of $1 \%$. The ARDL test obtains a long-term and short-run relationship between the variables, following the bounds test results to cointegration, which confirms linkage and co-integration among all selected variables. In addition, we performed several post-diagnostic tests, and the results are list in Table 6. The finding unveils our proposed model's smartness to tackle heteroscedasticity problems, misspecification, and residuals normality. So, the P-values of all these tests reflect 0.11 , $0.11,0.50$, and 0.68 , respectively. Sorely, there is also evidence of the structural break in Pakistan's agricultural 
productivity determinants during the research period. However, the post estimation graphs demonstrate the stability of the long-term coefficient with short-term movement in both equations using the cumulative sum (CUSUM) and the cumulative sum of square (CUSUMSQ) diagram, which is shown in Figures 2 and 3, respectively. Both figures reflect that the long-term coefficient framework is stable at the $5 \%$ level of significance.

Table 6: ARDL Bounds Test

\begin{tabular}{|c|c|c|c|c|c|c|}
\hline Model & F-statistics & Co-integration & $\chi^{2} \mathrm{ARCH}$ & $\chi^{2}$ RESET & $\chi^{2}$ Normality & $\chi^{2} \mathrm{LM}$ \\
\hline & $6.11^{*}$ & Yes & $2.41(0.11)$ & $1.60(0.11)$ & $1.35(0.50)$ & $0.79(0.68)$ \\
\hline & \multicolumn{2}{|c|}{$10 \%$} & \multicolumn{2}{|c|}{$5 \%$} & \multicolumn{2}{|c|}{$1 \%$} \\
\hline F-statistics & 2.26 & 3.35 & 2.62 & 3.79 & 3.41 & 4.68 \\
\hline
\end{tabular}

Note * represent a $1 \%$ level of significance

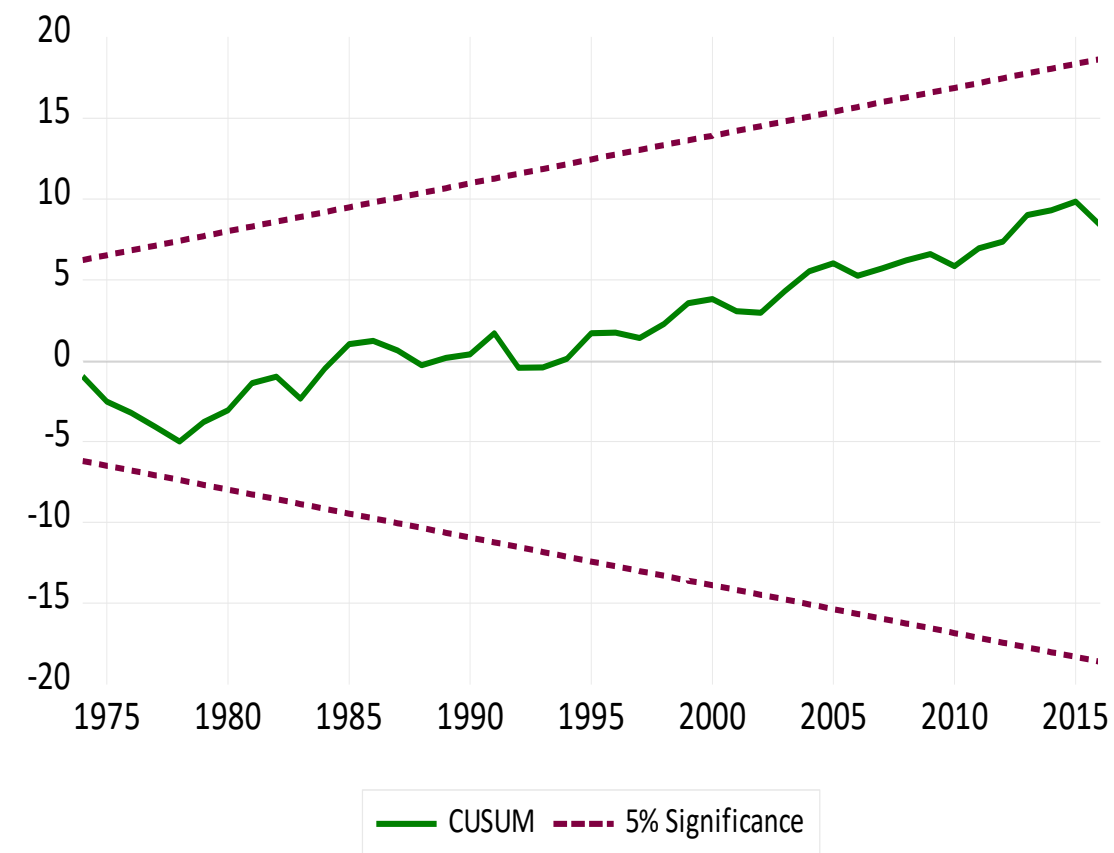

Figure 2. Cumulative Sum Plot for Stability 


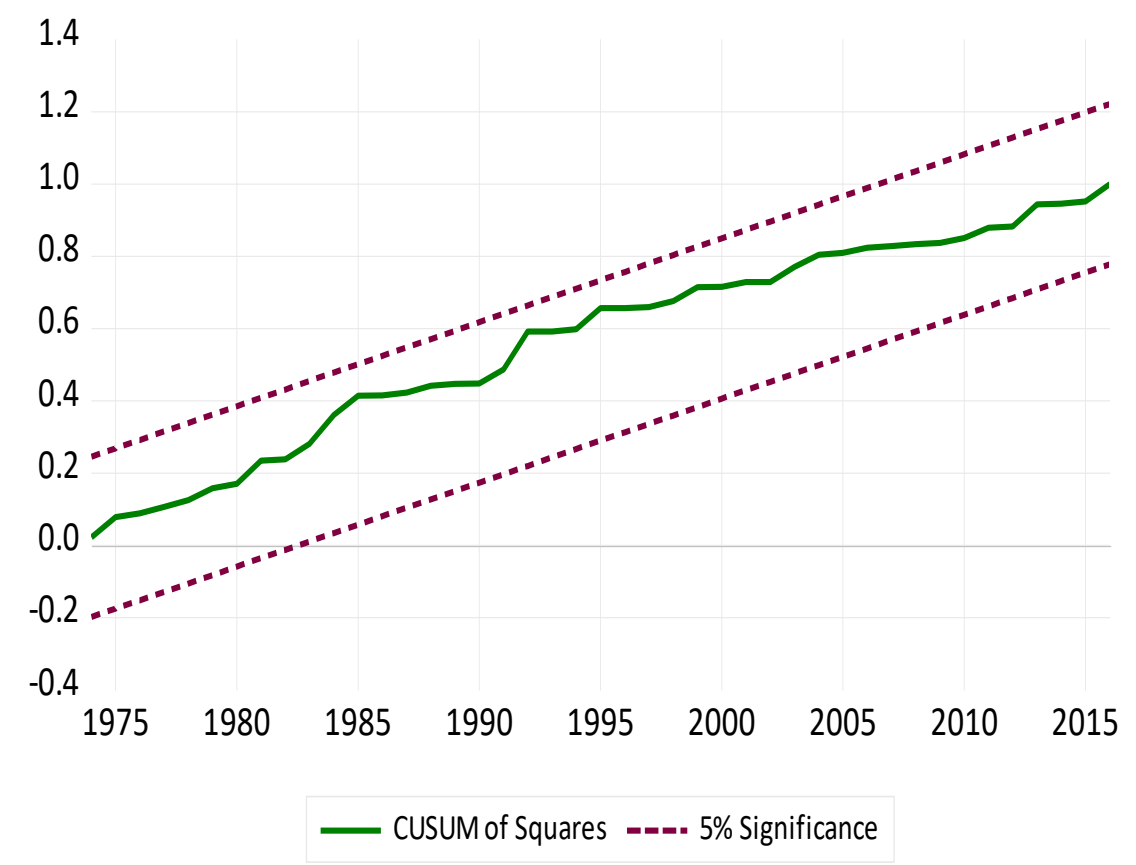

Figure 3. Cumulative Sum of Square Plot for Stability

After verifying the co-integration among agricultural productivity and its determinants, we discover short- and longterm dynamic linkage of these variables using the ARDL approach and illustrate the results in Table 7. The long-term ARDL estimates show that feeds positively and significantly connect with agricultural productivity, as the estimated coefficient value and its probability are 0.2132 and 0.005 , respectively. In other words, a $1 \%$ increase in feed leads to an upturn in the agricultural productivity of Pakistan by $0.21 \%$. Similarly, fertilizers' findings also positively impact agricultural productivity at the 5\% significance level. These outcomes confirm that a $1 \%$ increase in fertilizer would augment agricultural productivity by $0.07 \%$, exposing the maximum use of feed and fertilizer to increase Pakistan's agricultural production. As expected, rapid population growth will double the global demand for livestock and other agricultural products by 2050 .

Meanwhile, the increasing use of fertilizers in crops and livestock feeds to meet growing demand is a significant reason for increased greenhouse gas (GHG) emissions. Only livestock has contributed 14.5\% to global GHG emissions (Rojas-Downing et al., 2017). The drastic climate change is a significant threat to agricultural production, and mitigating this impact on agriculture has become a crucial challenge to save food for the coming generation. In this context, our feed and fertilizer coefficient values show better results for agricultural production in Pakistan; on the other hand, it would be alarming for environmental pollution. We need to develop serious policies to monitor and address feed and fertilizer use and limit it to acceptable food security levels and save the world from global warming. However, many scholars have researched to solve this problem and bring the real picture before the economies' policymakers (Appiah et al., 2018; Edoja et al., 2016). Experts believe that sustainable crop production is the only way to save the world from pollution and food security for the present and future generations. 
Moreover, sustainable agricultural production can be achieved by discouraging weak farming practices that affect the environment (Asumadu-Sarkodie and Owusu, 2017; Manandhar et al., 2018). The estimated cost of agricultural labor and land is 0.130 and 0.3227 , respectively, indicating a positive and significant linkage of these two vital factors with long-term agricultural productivity. Furthermore, these results mean that a $1 \%$ increase in farm labor and land results in a $0.13 \%$ and $0.32 \%$ increase in Pakistan's agricultural productivity. Interestingly, agricultural land's productive effect is larger than the agricultural labor, feed, and fertilizer used in agricultural activities, suitable for sustainable agriculture. Likewise, $\mathrm{CO}_{2}$ estimated value is 0.1711 , which reveals the positive and significant effect of environmental pollution on agricultural productivity. If we assume a $1 \%$ increase in Pakistan's CO2 emissions, it increased agricultural productivity by $0.17 \%$. This finding is in line with the results of (Manzoor Ahmad et al., 2021; Munir Ahmad et al., 2021; Khattak et al., 2020; Rehman et al., 2020). Furthermore, the term error correction term (ECT)'s negative coefficient value indicates the validity of short-term linkages between variables. As presented in Table 7, there is also a short-run linkage of agricultural productivity with agricultural feeds, fertilizers, labor, and land. Overall, the ARDL approach results show a long-term and short-run relationship between all variables of the study.

Table 7: ARDL Long and Short-run results

\begin{tabular}{cccc}
\hline Variable & Coefficient & t-Statistic & Prob. \\
\hline Long-Run Estimation & $0.2132^{*}$ & 2.9435 & 0.005 \\
FD & $0.0666^{* *}$ & 2.1115 & 0.041 \\
FT & $0.4292^{* * *}$ & 1.9991 & 0.053 \\
ALB & 0.0193 & 0.0861 & 0.631 \\
ALD & $0.1711^{* *}$ & 2.6699 & 0.011 \\
CO $_{2}$ & & & \\
Short-run Estimation & $0.213^{*}$ & 3.4095 & 0.001 \\
FD & $0.036^{*}$ & 2.0024 & 0.052 \\
FT & 0.130 & 0.7294 & 0.470 \\
ALB & 0.3227 & 1.1464 & 0.259 \\
ALD & $0.1711^{*}$ & 2.9224 & 0.006 \\
CO & $-0.652^{*}$ & -6.4635 & 0.000 \\
ECT(-1) & 0.99 & & \\
$\mathrm{R}^{2}$ & 0.98 & & \\
Adj R & & &
\end{tabular}

Note: $1 \%, 5 \%$ and $10 \%$ level of significance is depicted by $* * *$, and $* * *$ respectively

We further employed FMOLS and DOLS to measure the robustness of the outcome of long-term estimates of the ARDL approach. The results of these two tests clarify in table 8. As per the results, there is a positive and significant long-term relationship between agricultural productivity determinants, including feed, fertilizers, agricultural labor, 
and carbon emissions. However, agricultural land exerts a positive but insignificant effect on agricultural efficiency in Pakistan.

Table 8. Robustness Check

\begin{tabular}{ccccccc}
\hline \multirow{2}{*}{ Variable } & \multicolumn{3}{c}{ FMOLS } & & DOLS \\
\cline { 2 - 7 } & Coefficient & t-Statistic & Prob. & Coefficient & t-Statistic & Prob. \\
\hline FD & $0.2177^{*}$ & 5.1701 & 0.000 & $0.2132^{*}$ & 4.1017 & 0.000 \\
FT & $0.0692^{* *}$ & 3.7263 & 0.000 & $0.0666^{*}$ & 2.9423 & 0.007 \\
ALB & $0.0430^{*}$ & 2.9561 & 0.005 & $0.5278^{*}$ & 3.8161 & 0.000 \\
$\mathrm{ALD}$ & 0.0790 & 0.6034 & 0.550 & 0.0193 & 0.1200 & 0.905 \\
$\mathrm{CO}_{2}$ & $0.1654^{*}$ & 4.3717 & 0.000 & $0.1711^{*}$ & 3.7204 & 0.000 \\
$\mathrm{R}^{2}$ & & 0.99 & & & 0.99 & \\
Adj R & & 0.98 & & & 0.98 & \\
\hline
\end{tabular}

Note: $* * *$ and $* *$ depicts $1 \%, 5 \%$ and $10 \%$ respectively

The current research utilizes the wavelet transform coherence (WTC) approach to catching the causality and correlation between TPF and the regressors. This method is crafted from the domain of physics to obtain formerly undetected information. Therefore, the research investigates the connection in the short, medium, and long-run between TPF and its regressors. The cone of influence (COI) is the white where discussion is carried out in the WTC. The thick black contour delineates a level of significance, based on simulations of Monte Carlo. In Figures 4a-4e, 04, 4-8, and 8-16 manifests short, medium, and long-term relations correspondingly. The vertical and horizontal axis in the Figure depicts frequency and time. Blue and yellow colours represents low and high dependency between the series. In-phase (positive) and out-of-phase (negative) connections are described by rightward and leftward arrows respectively. The rightward-down (leftward-up) explains the first variable lead (cause) the second parameter while the rightward-up (leftward-down) depicts that second variable lead (cause) the first variable.

Figure 4a elucidates the WTC between TFP and Agric-Labor between 1961 and 2016 at different frequencies from 1965 to 1970 . From 2000 to 2005, the arrows are rightward-up, illustrating the TFP and Agric-Labor's positive interconnection. Thus, this infers an increase in TFP accompanies in Agric-Labor. Furthermore, Agric-Labor lead (cause) TFP, which signifies that Agric-labour can predict certain variation in TFP. Figure 4b shows the WTC between TFP and Agric-Land from 1961 to 2016 in Pakistan. The majority of the arrows are rightward-up, proving a strong connection (dependency) at different frequencies from 1965-1970 and 2000-2005. Therefore, a piece of positive evidence has found the correlation between TFP and Agric-Land. Moreover, Agric-Land lead (cause) TFP during this period and presents Agric-land can predict TFP. Figure 4c depicts the WTC between TFP and $\mathrm{CO}_{2}$ from 1961 to 2016 in Pakistan. The majority of the arrows are rightward-up, demonstrates a strong connection (dependency) at different frequencies from 1964-1975 and low and medium frequencies from 2000-2005. Also, $\mathrm{CO}_{2}$ leads (cause) total factor productivity during this period and clarifies a strong predictor of TFP. Figure 4d paints the WTC between TFP and feeds from 1961 to 2016. Similarly, Figure 4e gives a picture of the WTC between TFP and fertilizer from 1961 to 
2016. The majority of the arrows are rightward-up, indicating a strong connection (dependency) at different frequencies from 1965-1980 and low and medium frequencies from 1982-2010. Fertilizer lead (cause) TFP during this period, unfolding the fertilizers is a strong predictor of TFP. Hence, this concludes that fertilizer can predict significant variation in TFP.

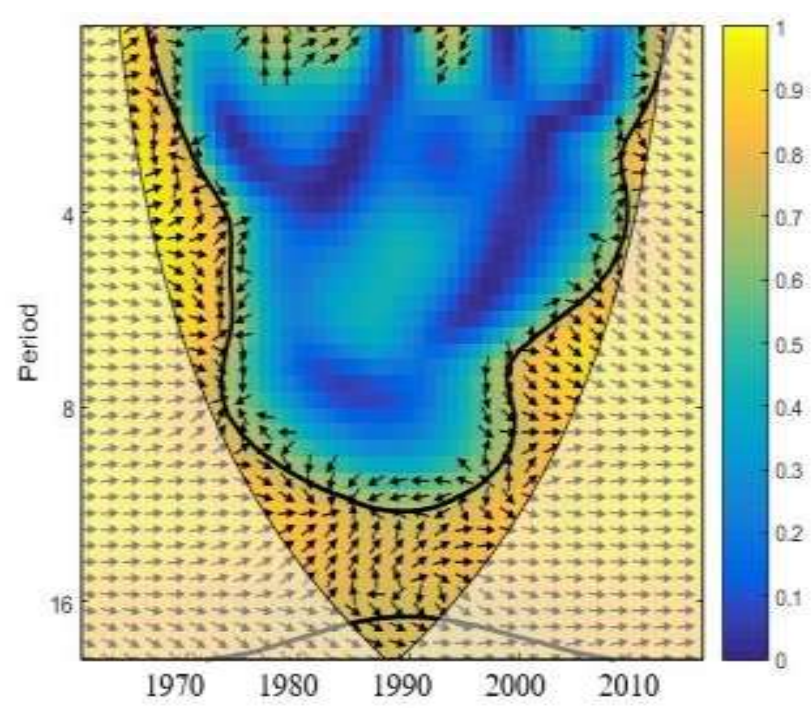

Fig 4a: WTC Between TFP \& AgricLabor

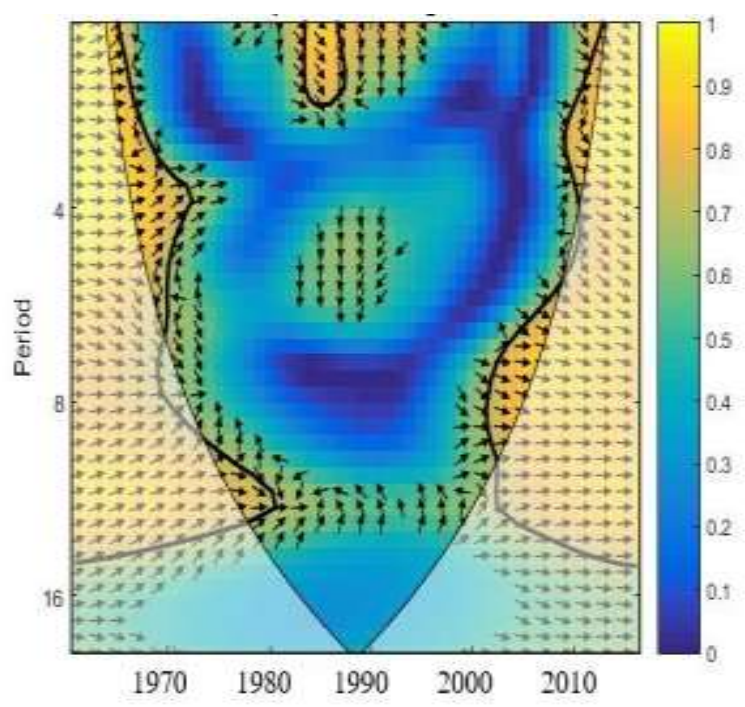

Fig 4b: WTC Between TFP \& Agric-Land

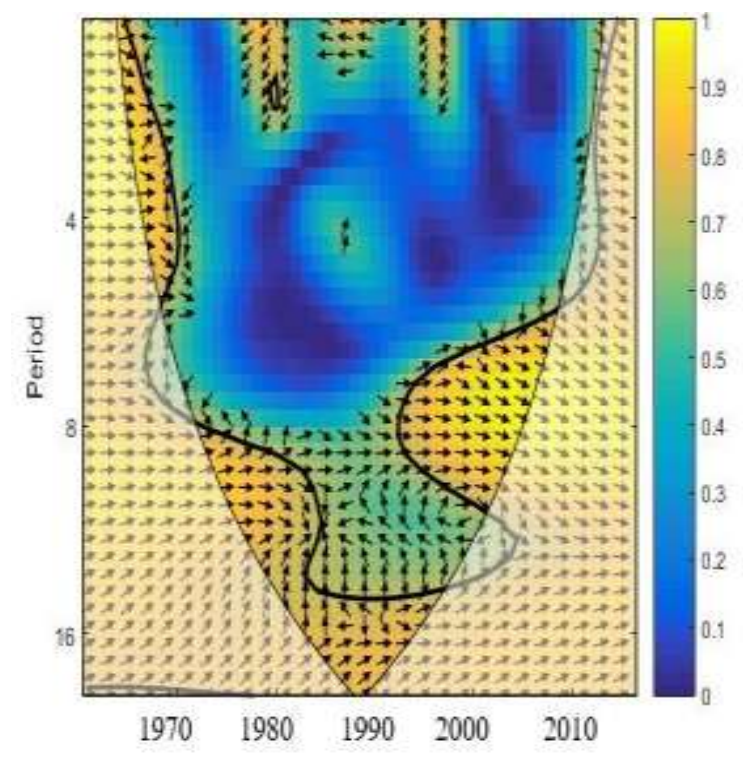

Fig 4c: WTC between TFP \& $\mathrm{CO}_{2}$ 


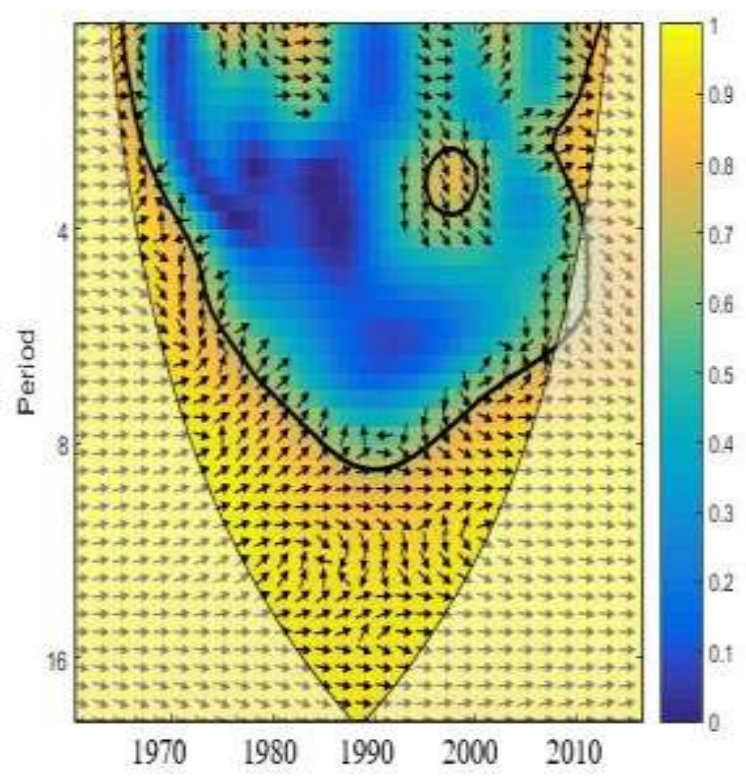

Fig 4d: WTC Between TFP \& Feed

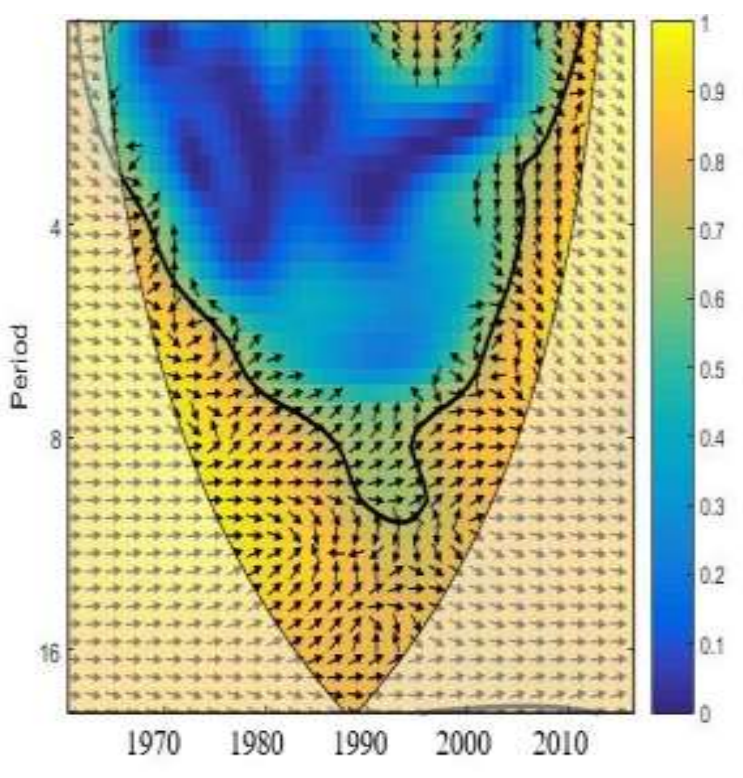

Fig 4e WTC Between TFP \& Fertilizer

Table 9: Gradual Shift Causality Test

\begin{tabular}{ccccc}
\hline Causality Path & Wald-stat & No of Fourier & P-Value & Decision \\
\hline ALB $\rightarrow$ TFP & $12.05439^{* * *}$ & 3 & 0.098784 & Reject Ho \\
TFP $\rightarrow$ ALB & 4.467524 & 3 & 0.724624 & Do not Reject Ho \\
ALD $\rightarrow$ TFP & 6.671819 & 2 & 0.463830 & Do not Reject Ho \\
TFP $\rightarrow$ ALD & $15.87455^{* *}$ & 2 & 0.026288 & Reject Ho \\
CO2 $\rightarrow$ TFP & $13.58028^{* *}$ & 3 & 0.059170 & Reject Ho \\
TFP $\rightarrow$ CO2 & 7.180727 & 3 & 0.410308 & Do not Reject Ho \\
FD $\rightarrow$ TFP & 7.724252 & 2 & 0.357536 & Do not Reject Ho \\
TFP $\rightarrow$ FD & 3.816134 & 2 & 0.800695 & Do not Reject Ho \\
FT $\rightarrow$ TFP & $17.27995^{*}$ & 1 & 0.015678 & Reject Ho \\
TFP $\rightarrow$ FT & 8.566952 & 1 & 0.285259 & Do not Reject Ho \\
\hline
\end{tabular}

Note: Significance level of $1 \%, 5 \%$ and $10 \%$ is depicted by $*, * *$ and $* * *$

Furthermore, we have utilized Toda-Yamamoto based Gradual Shift Causality technique to measure the unidirectional and bi-directional linkage between agricultural productivity and $\mathrm{CO}^{2}$ emission, land, labor, fertilizers, and feeds. Their results, listed in Table 9, reveal a uni-directional causality from agricultural labor to agricultural productivity at the $10 \%$ significance level. Similarly, this test has found a one-way causality from factor productivity to agricultural land, from $\mathrm{CO}_{2}$ to agricultural productivity, and from fertilizers to productivity. This further means that labor, $\mathrm{CO}_{2}$, and fertilizers cause the agricultural productivity in Pakistan, while the factor productivity only causes 
agricultural land. Besides, the findings of this causality test also support the graphical measures of the wavelet technique.

\section{Conclusion and Policy Implications}

This study mainly explores the real picture of the linkages between agricultural productivity and its determinants such as $\mathrm{CO}_{2}$ emissions, agricultural lands, labor, feeds and fertilizers using the recent time-series data spanning from 1961 to 2016. In the first phase, the study examined the order of integration utilizing the ADF, PP, and ZA unit root tests and founds a mixture of level I ( 0 ) and the first difference I (I) data stationery. Since then, the ARDL bounds test has been employed, discovering the Cointegration relationship between the study variables at a $5 \%$ significance level. Meanwhile, the subsequent approach is ARDL with the error correction term, which we applied to capture the longterm and short-term linkages among agricultural productivity and the regressors. These findings exposed that the $\mathrm{CO}_{2}$ emissions, agricultural land, labor, feed, and fertilizers have a positive and significant long-run impact on Pakistan's agricultural efficiency. Likewise, each regressors has a positive and considerable influence on productivity, excluding labor, as it has a positive but insignificant association with the outcome variable. Our findings' robustness has been verified utilizing the FMOLS and DOLS approach, which indicates our results almost robust and stable. The wavelet coherence technique has been employed as it has the advantage of capturing correlation and causality simultaneously at different levels of frequencies and periods. Subsequently, we applied the Toda-Yamamoto causality techniques to measure the long-term causality between agricultural productivity and all explanatory variables. This gradual shift causality test has the benefit of detecting causal linkage among factors even in the presence of structural breaks in series. In the context of the gradual shift causality test results, agricultural labor, $\mathrm{CO}_{2}$ emissions, and fertilizers have a one-way relationship with agricultural productivity. In contrast, productivity has a uni-directional causal link with agricultural land.

Overall, this study has contributed to the current literature by proving that the determinants included have been validated because they have explained $99 \%$ agricultural productivity changes. It is proven that $\mathrm{CO}_{2}$ emissions, land, labor, fertilizer, and feed have a positive and significant impact on agricultural performance in the long and short term. We make the following policy recommendations based on the experimental results of the study: (a) Considerably, Pakistan's most agriculture is semi-arid; in fact, it is vulnerable to climate change shocks. It needs the hours to strengthen Pakistan's agricultural sector to resilience against extreme weather such as heat, drought, cold, and floods to meet sustainable yield in agriculture, as it is observed that the summer season has been intensifying for the past decade. Furthermore, substantial investments and policies are needed to protect and strengthen production against pests and diseases. It has also increased, and farmers use more and more pesticides and bio-control. As a result, the environment deteriorated. Therefore, this is possible only when we encourage public, private investment, and public policy reforms in agricultural research, seed systems, agricultural input markets, and expansion to help farmers. (b) As our results show, Pakistan's agricultural land has a relatively low impact on long-term productivity. It might be due to multiple reasons such as soil salinity, waterlogging, lack of soil fertility, soil erosion, climate effects, and distribution of canal water inequality. These all problems and salinization of the soil severely deplete the soil's productivity and significantly reduce crop yields. In this context, some policy reforms and productive research are 
desirable to create better ways to use fertilizers and water more efficiently to save Pakistan's future productivity. Furthermore, policies need to formulate to make better use of the largest network of canals as Pakistan has the most extensive canal roots that have the potential benefit to store water and generate renewable energy. These are the ones that can help protect and preserve the environment from the harmful waste of traditional semi-arid agriculture.

\section{Declarations}

1. Manuscript Compliance with Ethical Standard

2. There is no Conflict of Interest

3. Supplementary Data available-S1

4. Author's Contributions

Muhammad Ramzan- Main theme, data collection, Introduction, methodology, interpretations, conclusion and policy implications.

Hafiz Arslan Iqbal- Introduction and Literature Review

Tomiwa- Methodology and Data Analysis 


\section{References}

A, G., J, M., 1984. “Decomposition of Hardy Functions into Square Integrable Wavelets of Constant Shape.” J. Math. Anal. 15, 723-736.

Abbas, G., Ahmad, S., Ahmad, A., Nasim, W., Fatima, Z., Hussain, S., Rehman, M.H. ur, Khan, M.A., Hasanuzzaman, M., Fahad, S., Boote, K.J., Hoogenboom, G., 2017. Quantification the impacts of climate change and crop management on phenology of maize-based cropping system in Punjab, Pakistan. Agric. For. Meteorol. 247, 42-55. https://doi.org/10.1016/j.agrformet.2017.07.012

Adebayo, T. S., 2020. Revisiting the EKC hypothesis in an emerging market: an application of ARDL-based bounds and wavelet coherence approaches. SN Applied Sciences, 2(12), 1-15.

Adebayo, T.S., Akinsola, G.D., 2020. Investigating the causal linkage among economic growth, energy consumption and co2 emissions in thailand: An application of the wavelet coherence approach. Int. J. Renew. Energy Dev. 10, 17-26. https://doi.org/10.14710/ijred.2021.32233

Adebayo, T.S., Odugbesan, J.A., 2020. Modeling CO2 emissions in South Africa: emapirical evidence from ARDL based bounds and wavelet coherence techniques. Environ. Sci. Pollut. Res. https://doi.org/10.1007/s11356$020-11442-3$

Ahmad, D., Afzal, M., 2020. Climate change adaptation impact on cash crop productivity and income in Punjab province of Pakistan. Environ. Sci. Pollut. Res. 27, 30767-30777. https://doi.org/10.1007/s11356-020-09368$\mathrm{x}$

Ahmad Jan, S., Bibi, N., Khan Shinwari, Z., Ashiq Rabbani, M., Ullah, S., Qadir, A., Khan, N., 2017. Impact of salt, drought, heat and frost stresses on morpho-biochemical and physiological properties of Brassica species: An updated review. J. Rural Dev. Agric. 2, 1-10.

Ahmad, Manzoor, Khan, Z., Rahman, Z.U., Khattak, S.I., Khan, Z.U., 2021. Can innovation shocks determine CO2 emissions (CO2e) in the OECD economies? A new perspective. Econ. Innov. New Technol. 30, 89-109. https://doi.org/10.1080/10438599.2019.1684643

Ahmad, Munir, Rehman, A., Shah, S.A.A., Solangi, Y.A., Chandio, A.A., Jabeen, G., 2021. Stylized heterogeneous dynamic links among healthcare expenditures, land urbanization, and $\mathrm{CO} 2$ emissions across economic development levels. Sci. Total Environ. 753. https://doi.org/10.1016/j.scitotenv.2020.142228

Ahmad, S., Nadeem, M., Abbas, G., Fatima, Z., Zeb Khan, R.J., Ahmed, M., Ahmad, A., Rasul, G., Azam Khan, M., 2016. Quantification of the effects of climate warming and crop management on sugarcane phenology. Clim. Res. 71, 47-61. https://doi.org/10.3354/cr01419

Ahmad, S., Tariq, M., Hussain, T., Abbas, Q., Elham, H., Haider, I., Li, X., 2020. Does Chinese FDI, climate change, and $\mathrm{CO} 2$ emissions stimulate agricultural productivity? An empirical evidence from Pakistan. Sustain. 
12. https://doi.org/10.3390/SU12187485

Ahsan, F., Chandio, A.A., Fang, W., 2020. Climate change impacts on cereal crops production in Pakistan. Int. J. Clim. Chang. Strateg. Manag. 12, 257-269. https://doi.org/10.1108/ijccsm-04-2019-0020

Ainsworth, E.A., Yendrek, C.R., Sitch, S., Collins, W.J., Emberson, L.D., 2012. The effects of tropospheric ozone on net primary productivity and implications for climate change. Annu. Rev. Plant Biol. 63, 637-661. https://doi.org/10.1146/annurev-arplant-042110-103829

Alam, A., Azam, M., Abdullah, A. Bin, Malik, I.A., Khan, A., Hamzah, T.A.A.T., Faridullah, Khan, M.M., Zahoor, H., Zaman, K., 2015. Environmental quality indicators and financial development in Malaysia: unity in diversity. Environ. Sci. Pollut. Res. 22, 8392-8404. https://doi.org/10.1007/s11356-014-3982-5

Alexandratos, Nikos ; Bruinsma, J.F., 2012. World Agriculture Towards 2030/2015: The 2012 Revision. ESA Work. Pap. No. 12-03. https://doi.org/10.1016/S0264-8377(03)00047-4

Ali, S., Liu, Y., Ishaq, M., Shah, T., Abdullah, Ilyas, A., Din, I., 2017. Climate Change and Its Impact on the Yield of Major Food Crops: Evidence from Pakistan. Foods 6, 39. https://doi.org/10.3390/foods6060039

Ali, S., Ying, L., Anjum, R., Nazir, A., Shalmani, A., Shah, T., Shah, F., 2020. Analysis on the nexus of CO2 emissions, energy use, net domestic credit, and GDP in Pakistan: an ARDL bound testing analysis. Environ. Sci. Pollut. Res. https://doi.org/10.1007/s11356-020-10763-7

Alola, A. A., Bekun, F. V., \& Sarkodie, S. A. (2019). Dynamic impact of trade policy, economic growth, fertility rate, renewable and non-renewable energy consumption on ecological footprint in Europe. Science of the Total Environment, 685, 702-709.

Anjum, A.S., Zada, R., Tareen, W.H., 2016. Organic farming: Hope for the sustainable livelihoods of future generations in Pakistan. J. Rural Dev. Agric. 1, 20-29.

Aragón, F.M., Oteiza, F., Rud, J.P., 2019. Climate change and agriculture: Subsistence farmers' response to extreme heat. arXiv. https://doi.org/10.1257/pol.20190316

Asumadu-Sarkodie, S., Owusu, P.A., 2017. Recent evidence of the relationship between carbon dioxide emissions, energy use, GDP, and population in Ghana: A linear regression approach. Energy Sources, Part B Econ. Plan. Policy 12, 495-503. https://doi.org/10.1080/15567249.2016.1208304

Asumadu-Sarkodie, S., Owusu, P.A., 2016. The relationship between carbon dioxide and agriculture in Ghana: a comparison of VECM and ARDL model. Environ. Sci. Pollut. Res. 23, 10968-10982. https://doi.org/10.1007/s11356-016-6252-x

Attiaoui, I., Boufateh, T., 2019. Impacts of climate change on cereal farming in tunisia: A panel ARDL-PMG approach. Environ. Sci. Pollut. Res. 26, 13334-13345. https://doi.org/10.1007/s11356-019-04867-y 
Aziz, N., Sharif, A., Raza, A., Rong, K., 2020. Revisiting the role of forestry, agriculture, and renewable energy in testing environment Kuznets curve in Pakistan: evidence from Quantile ARDL approach. Environ. Sci. Pollut. Res. 27, 10115-10128. https://doi.org/10.1007/s11356-020-07798-1

Banday, U.J., Aneja, R., 2019. Energy consumption, economic growth and CO 2 emissions: evidence from G7 countries . World J. Sci. Technol. Sustain. Dev. 16, 22-39. https://doi.org/10.1108/wjstsd-01-2018-0007

Burakov, D., 2019. Does agriculture matter for environmental Kuznets curve in Russia: Evidence from the ARDL bounds tests approach. Agris On-line Pap. Econ. Informatics 11, 23-34. https://doi.org/10.7160/aol.2019.110303

Chandio, A.A., Jiang, Y., Rehman, A., Rauf, A., 2020. Short and long-run impacts of climate change on agriculture: an empirical evidence from China. Int. J. Clim. Chang. Strateg. Manag. 12, 201-221. https://doi.org/10.1108/IJCCSM-05-2019-0026

Dharmasiri, L.M., 2012. Measuring Agricultural Productivity Using the Average Productivity Index (API). Sri Lanka J. Adv. Soc. Stud. 1. https://doi.org/10.4038/sljass.v1i2.4855

Di Gregorio, M., Nurrochmat, D.R., Paavola, J., Sari, I.M., Fatorelli, L., Pramova, E., Locatelli, B., Brockhaus, M., Kusumadewi, S.D., 2017. Climate policy integration in the land use sector: Mitigation, adaptation and sustainable development linkages. Environ. Sci. Policy 67, 35-43. https://doi.org/10.1016/j.envsci.2016.11.004

DS, B., RL., N., 2009. Historical warnings of future food insecurity with unprecedented seasonal heat. Science (80-. ). $323,240-44$.

Eckstein, D., Künzel, V., Schäfer, L., 2020. Global climate risk index 202128.

Elliott, G., Rothenberg, T.J., Stock, J.H., 1996. Efficient Tests for an Autoregressive Unit Root. Econometrica 64, 813. https://doi.org/10.2307/2171846

Enders, W., Jones, P., 2016. Grain prices, oil prices, and multiple smooth breaks in a VAR. Stud. Nonlinear Dyn. Econom. 20, 399-419. https://doi.org/10.1515/snde-2014-0101

Fan, W., M. Carroll, C., 2012. Regional trend of climatic change in the USA. World J. Sci. Technol. Sustain. Dev. 9, 38-44. https://doi.org/10.1108/20425941211223615

Figueiredo, F., Gomes, M.I., Henriques-Rodrigues, L., Miranda, M.C., 2012. A computational study of a quasiPORT methodology for VaR based on second-order reduced-bias estimation. J. Stat. Comput. Simul. 82, 587602. https://doi.org/10.1080/00949655.2010.547196

Godfray, H.C.J., Beddington, J.R., Crute, I.R., Haddad, L., Lawrence, D., Muir, J.F., Pretty, J., Robinson, S., Thomas, S.M., Toulmin, C., 2010. Food security: The challenge of feeding 9 billion people. Science (80-. ). 327, 812-818. https://doi.org/10.1126/science.1185383 
Gokmenoglu, K.K., Taspinar, N., Kaakeh, M., 2019. Agriculture-induced environmental Kuznets curve: the case of China. Environ. Sci. Pollut. Res. 26, 37137-37151. https://doi.org/10.1007/s11356-019-06685-8

Heck, W.W., Taylor, O.C., Tingey, D.T., 1988. Assessment of crop loss from air pollutants. Assess. Crop loss from air Pollut. https://doi.org/10.2134/jeq1990.00472425001900040025x

Husnain, M.I.U., Subramanian, A., Haider, A., 2018. Robustness of geography as an instrument to assess impact of climate change on agriculture. Int. J. Clim. Chang. Strateg. Manag. 10, 654-669.

https://doi.org/10.1108/IJCCSM-03-2017-0049

JA. Foley, N.Ramankutty, KA. Brauman, ES. Cassidy, JS. Gerber, M.J., 2013. Solutions for a cultivated planet.

Janjua, P.Z., Samad, G., Khan, N., 2014. Climate change and wheat production in Pakistan: An autoregressive distributed lag approach. NJAS - Wageningen J. Life Sci. 68, 13-19. https://doi.org/10.1016/j.njas.2013.11.002

Khan, Z., Sisi, Z., Siqun, Y., 2019. Environmental regulations an option: Asymmetry effect of environmental regulations on carbon emissions using non-linear ARDL. Energy Sources, Part A Recover. Util. Environ. Eff. 41, 137-155. https://doi.org/10.1080/15567036.2018.1504145

Khattak, S.I., Ahmad, M., Khan, Z.U., Khan, A., 2020. Exploring the impact of innovation, renewable energy consumption, and income on $\mathrm{CO} 2$ emissions: new evidence from the BRICS economies. Environ. Sci. Pollut. Res. 27, 13866-13881. https://doi.org/10.1007/s11356-020-07876-4

Kirikkaleli, D., \& Adebayo, T. S., 2020. Do renewable energy consumption and financial development matter for environmental sustainability? New global evidence. Sustainable Development.

Kirikkaleli, D., Gokmenoglu, K.K., 2020. Sovereign credit risk and economic risk in Turkey: Empirical evidence from a wavelet coherence approach. Borsa Istanbul Rev. 20, 144-152. https://doi.org/10.1016/j.bir.2019.06.003

Koondhar, M.A., Li, H., Wang, H., Bold, S., Kong, R., 2020. Looking back over the past two decades on the nexus between air pollution, energy consumption, and agricultural productivity in China: a qualitative analysis based on the ARDL bounds testing model. Environ. Sci. Pollut. Res. 27, 13575-13589. https://doi.org/10.1007/s11356-019-07501-z

Kousar, S., Shabbir, A., 2021. Analysis of environmental degradation mechanism in the nexus among energy consumption and poverty in Pakistan. Environ. Sci. Pollut. Res. https://doi.org/10.1007/s11356-020-12140-w

Kurukulasuriya, P., Mendelsohn, R., Hassan, R., Benhin, J., Deressa, T., Diop, M., Eid, H.M., Fosu, K.Y., Gbetibouo, G., Jain, S., Mahamadou, A., Mano, R., Kabubo-Mariara, J., El-Marsafawy, S., Molua, E., Ouda, S., Ouedraogo, M., Séne, I., Maddison, D., Seo, S.N., Dinar, A., 2006. Will African agriculture survive climate change? World Bank Econ. Rev. 20, 367-388. https://doi.org/10.1093/wber/lhl004 
Lashkari, A., Alizadeh, A., Rezaei, E.E., Bannayan, M., 2012. Mitigation of climate change impacts on maize productivity in northeast of Iran: A simulation study. Mitig. Adapt. Strateg. Glob. Chang. 17, 1-16. https://doi.org/10.1007/s11027-011-9305-y

Liang, X.Z., Wu, Y., Chambers, R.G., Schmoldt, D.L., Gao, W., Liu, C., Liu, Y.A., Sun, C., Kennedy, J.A., 2017. Determining climate effects on US total agricultural productivity. Proc. Natl. Acad. Sci. U. S. A. 114, E2285E2292. https://doi.org/10.1073/pnas.1615922114

Lobell, D.B., Hammer, G.L., Chenu, K., Zheng, B., Mclean, G., Chapman, S.C., 2015. The shifting influence of drought and heat stress for crops in northeast Australia. Glob. Chang. Biol. 21, 4115-4127. https://doi.org/10.1111/gcb.13022

Mahrous W, 2018. Dynamic impacts of climate change on cereal yield in Egypt: An ARDL model. Financ. Walaa Mahrous - J. Econ.

Manandhar, T., Prashad, B., Nath Pal, M., 2018. Risk Factors for Intrauterine Growth Restriction and Its Neonatal Outcome. Gynecol. Obstet. 08. https://doi.org/10.4172/2161-0932.1000464

Matthew, O., Osabohien, R., Fagbeminiyi, F., Fasina, A., 2018. Greenhouse gas emissions and health outcomes in Nigeria: Empirical insight from auto-regressive distribution lag technique. Int. J. Energy Econ. Policy 8, 4350 .

Mehmood, U., 2020. Globalization-driven CO2 emissions in Singapore: an application of ARDL approach. Environ. Sci. Pollut. Res. https://doi.org/10.1007/s11356-020-11368-w

Mendelsohn, R., 2014. The impact of climate change on agriculture in Asia. J. Integr. Agric. 13, 660-665. https://doi.org/10.1016/S2095-3119(13)60701-7

Naseem, S., Guang Ji, T., Kashif, U., 2020. Asymmetrical ARDL correlation between fossil fuel energy, food security, and carbon emission: providing fresh information from Pakistan. Environ. Sci. Pollut. Res. 27, 31369-31382. https://doi.org/10.1007/s11356-020-09346-3

Nazlioglu, S., Gormus, N.A., Soytas, U., 2016. Oil prices and real estate investment trusts (REITs): Gradual-shift causality and volatility transmission analysis. Energy Econ. 60, 168-175. https://doi.org/10.1016/j.eneco.2016.09.009

Odugbesan, J.A., Adebayo, T.S., 2020. The symmetrical and asymmetrical effects of foreign direct investment and financial development on carbon emission: evidence from Nigeria. SN Appl. Sci. 2. https://doi.org/10.1007/s42452-020-03817-5

Ozturk, I., 2015. Measuring the impact of energy consumption and air quality indicators on climate change: evidence from the panel of UNFCC classified countries. Environ. Sci. Pollut. Res. 22, 15459-15468. https://doi.org/10.1007/s11356-015-4757-3 
Pakistan, 2020. Pakistan Economic Survey 2019-20. Econ. Surv. Islam. Econ. Advis. Wing, Minist. Financ.

Parker, L., Bourgoin, C., Martinez-Valle, A., Läderach, P., 2019. Vulnerability of the agricultural sector to climate change: The development of a pan-tropical Climate Risk Vulnerability Assessment to inform sub-national decision making. PLoS One 14. https://doi.org/10.1371/journal.pone.0213641

Pesaran, M.H. and Shin, Y., 1998. An Autoregressive Distributed Lag Modelling Approach to Cointegration Analysis. Econom. Econ. Theory 20th Century Ragnar Frisch Centen. Symp. 371-413.

Pesaran, M.H., Shin, Y., Smith, R.J., 2001. Bounds testing approaches to the analysis of level relationships. J. Appl. Econom. 16, 289-326. https://doi.org/10.1002/jae.616

Phillips, P.C.B., Perron, P., 1988. Testing for a Unit Root in Time Series Regression. Biometrika 75, 335. https://doi.org/10.2307/2336182

Pla, C., Fernandez-Cortes, A., Cuezva, S., Galiana-Merino, J.J., Canãveras, J.C., Sanchez-Moral, S., Benavente, D., 2020. Insights on Climate-Driven Fluctuations of Cave 222Rn and CO2Concentrations Using Statistical and Wavelet Analyses. Geofluids 2020. https://doi.org/10.1155/2020/8858295

Proskurowski, G., Lilley, M.D., Seewald, J.S., Früh-Green, G.L., Olson, E.J., Lupton, J.E., Sylva, S.P., Kelley, D.S., 2008. Prioritizing Climate Change Adaptation Needs for Food Security in 2030. Science (80-. ). 319, 604607.

Rafindadi, A.A., Yusof, Z., Zaman, K., Kyophilavong, P., Akhmat, G., 2014. The relationship between air pollution, fossil fuel energy consumption, and water resources in the panel of selected Asia-Pacific countries. Environ. Sci. Pollut. Res. 21, 11395-11400. https://doi.org/10.1007/s11356-014-3095-1

Rashid, M., Husnain, Z., Shakoor, U., ul Husnain, M.I., 2020. Impact of climate change on cotton production in Pakistan: An ARDL bound testing approach. Sarhad J. Agric. 36, 333-341. https://doi.org/10.17582/JOURNAL.SJA/2020/36.1.333.341

Rehman, A., Ma, H., Irfan, M., Ahmad, M., 2020. Does carbon dioxide, methane, nitrous oxide, and GHG emissions influence the agriculture? Evidence from China. Environ. Sci. Pollut. Res. 27, 28768-28779. https://doi.org/10.1007/s11356-020-08912-z

Rehman, A., Ozturk, I., Zhang, D., 2019. The causal connection between CO2 emissions and agricultural productivity in Pakistan: Empirical evidence from an autoregressive distributed lag bounds testing approach. Appl. Sci. 9. https://doi.org/10.3390/app9081692

Schmidhuber, J., Tubiello, F.N., 2007. Global food security under climate change. Proc. Natl. Acad. Sci. U. S. A. 104, 19703-19708. https://doi.org/10.1073/pnas.0701976104

Sharif, A., Afshan, S., Chrea, S., Amel, A., Khan, S.A.R., 2020. The role of tourism, transportation and globalization in testing environmental Kuznets curve in Malaysia: new insights from quantile ARDL 
approach. Environ. Sci. Pollut. Res. 27, 25494-25509. https://doi.org/10.1007/s11356-020-08782-5

Sharmila Raisa, T., Chowdhury, S., Professor, A., Rahman, M., 2020. A NEXUS AMONG AIR POLLUTION, ENERGY CONSUMPTION AND AGRICULTURAL PRODUCTIVITY IN BANGLADESH: AN ARDL MODEL WITH STRUCTURAL BREAK Analysis of some aspects that influence employees' performance in Bangladesh View project A NEXUS AMONG AIR POLLUTION, ENERGY CONSUMPTION AND AGRICULTURAL PRODUCTIVITY IN BANGLADESH: AN ARDL MODEL WITH STRUCTURAL BREAK. Int. J. Manag. (IJM 11, 93-103. https://doi.org/10.34218/IJM.11.7.2020.010

Shoko, R.R., Belete, A., Chaminuka, P., 2019. Maize Yield Sensitivity To Climate Variability in South Africa: Application of the Ardl-Ecm Approac. J. Agribus. Rural Dev. 54. https://doi.org/10.17306/j.jard.2019.01201

Sims, C.A., 1980. Macroeconomics and Reality. Econometrica 48, 1. https://doi.org/10.2307/1912017

Torrence, C., Compo, G.P., 1998. A Practical Guide to Wavelet Analysis. Bull. Am. Meteorol. Soc. 79, 61-78. https://doi.org/10.1175/1520-0477(1998)079<0061:APGTWA>2.0.CO;2

Ukhurebor, K.E., Aigbe, U.O., Onyancha, R.B., Adetunji, C.O., 2021. Climate Change and Pesticides: Their Consequence on Microorganisms 83-113. https://doi.org/10.1007/978-981-15-7459-7_5

UNICEF, 2018. National Nutrition Survey 2018: Key Finding Report. Gov. Pakistan UNICEF Pakistan 2018.

Wajiha, I., Qadir, S., 2016. Roles of women in agriculture : A case study of rural Lahore, Pakistan. J. Rural Dev. Agric. 1, 1-11.

Warsame, A.A., Sheik-Ali, I.A., Ali, A.O., Sarkodie, S.A., 2021. Climate change and crop production nexus in Somalia: an empirical evidence from ARDL technique. Environ. Sci. Pollut. Res. https://doi.org/10.1007/s11356-020-11739-3

Weeks, D.P.C.C.L.E.Y.N. to K. in 20, 2015. Sustainable Development Report 2020. Dk 53, 1689-1699.

Wheeler, T., Von Braun, J., 2013. Climate change impacts on global food security. Science (80-. ). 341, 508-513. https://doi.org/10.1126/science.1239402

Y.Toda, H., Taku Yamamoto, 1995. Statistical Inference in Vector Autoregressions with Possibly Integrated Processes. J. Econom. 66, 225-250.

Zhou, L., Chen, X., Tian, X., 2018. The impact of fine particulate matter (PM2.5) on China's agricultural production from 2001 to 2010. J. Clean. Prod. 178, 133-141. https://doi.org/10.1016/j.jclepro.2017.12.204

Zivin, J.G., Neidell, M., 2018. Air pollution's hidden impacts. Science (80-. ). 359, 39-40. https://doi.org/10.1126/science.aap7711

Zivot, E., Andrews, D.W.K., 1992. Further Evidence on the Great Crash, the Oil-Price Shock, and the Unit-Root Hypothesis. J. Bus. Econ. Stat. 10, 251. https://doi.org/10.2307/1391541 

Figures

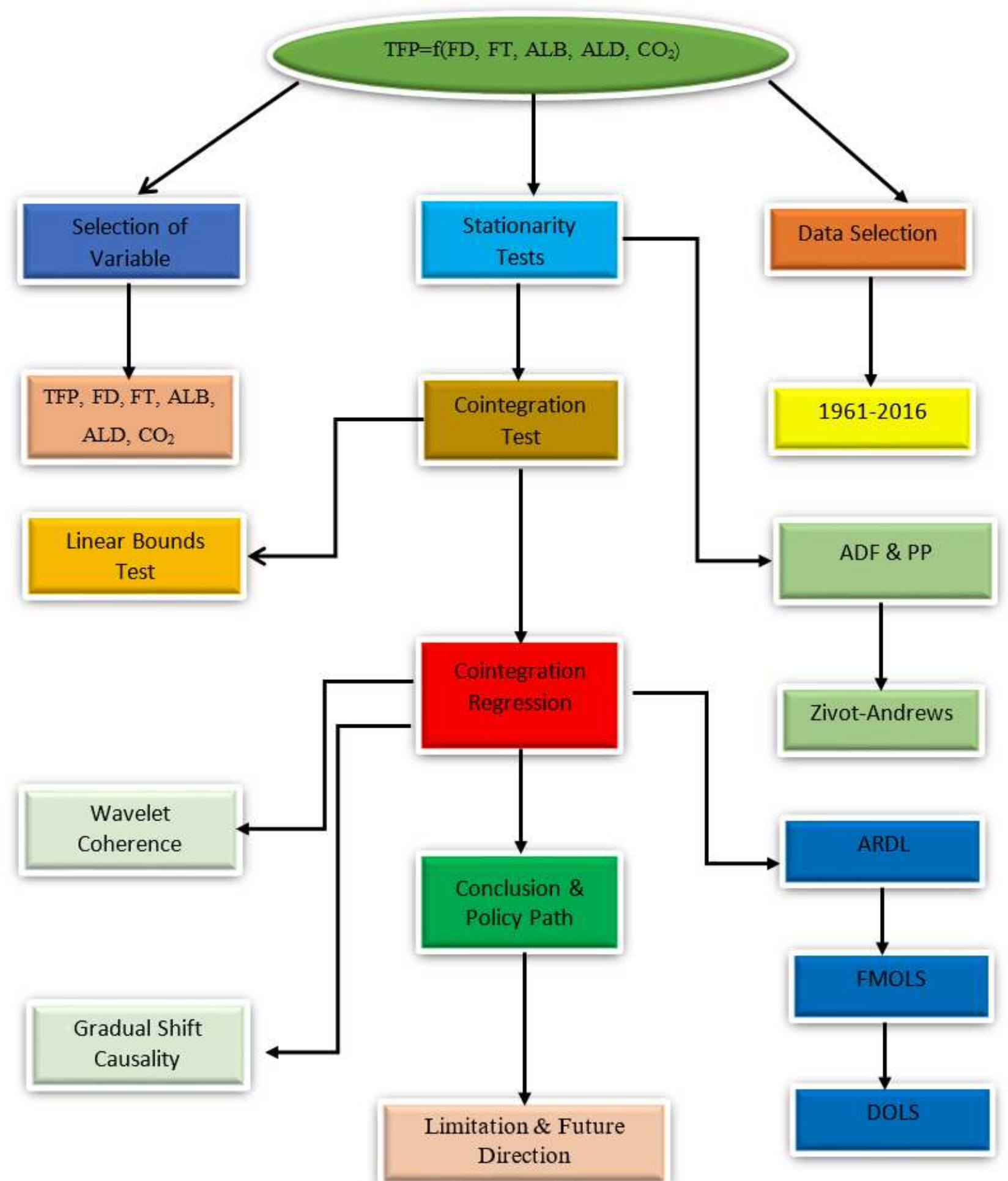

Figure 1

Flow Chart 


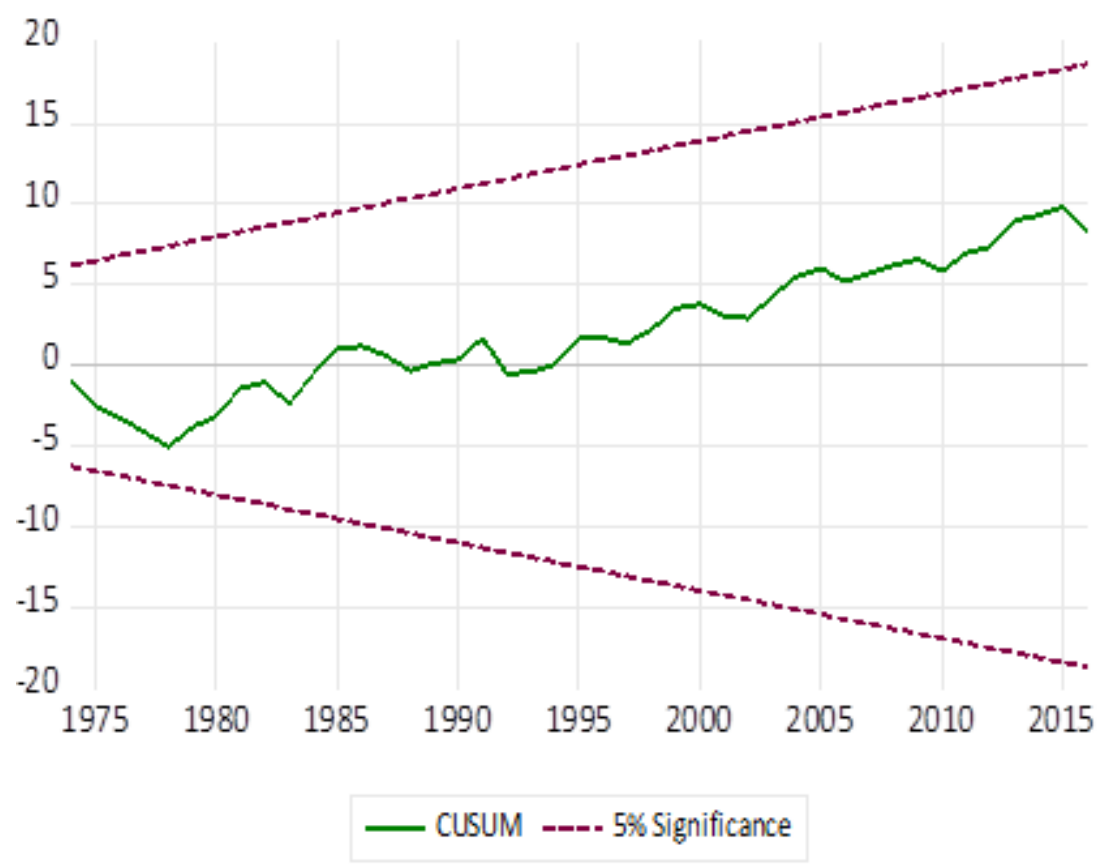

Figure 2

Cumulative Sum Plot for Stability

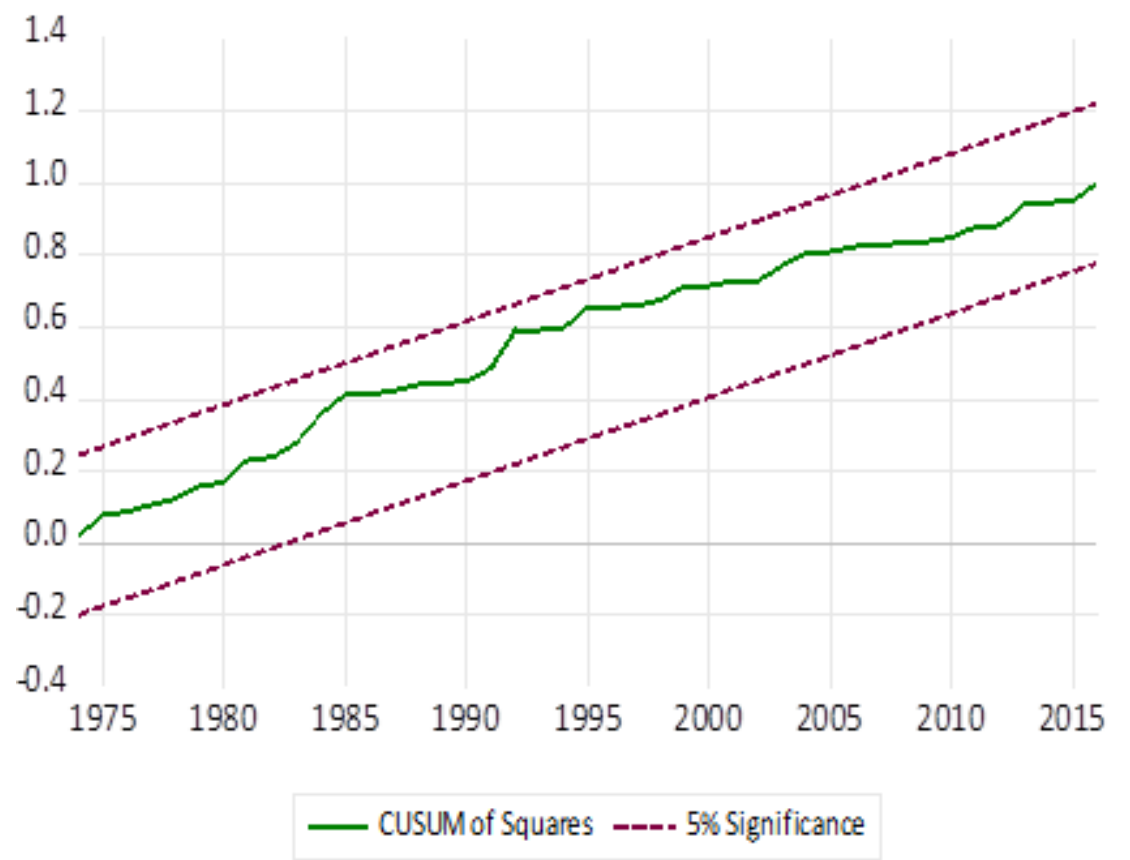

Figure 3

Cumulative Sum of Square Plot for Stability 


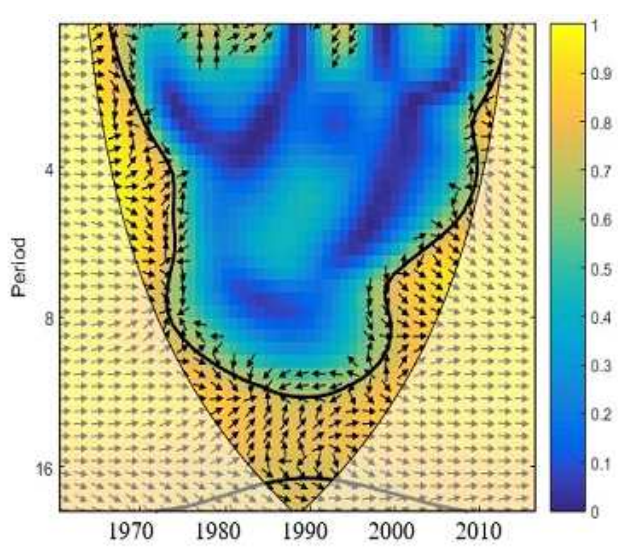

a: WTC Between TFP \& AgricL abor

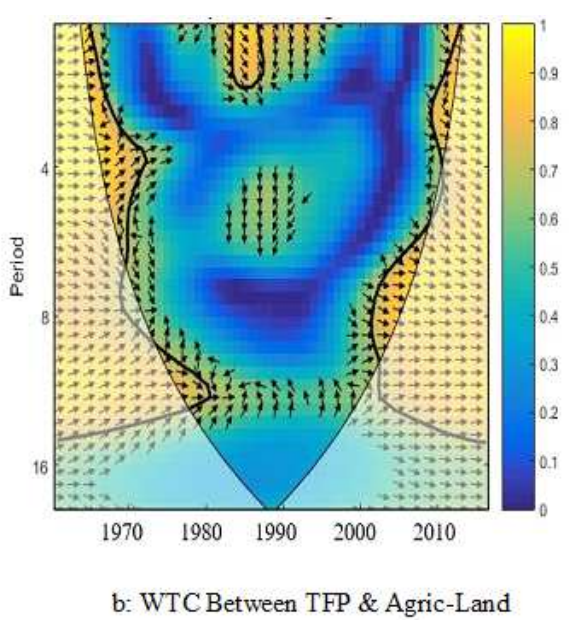

b: WTC Between TFP \& Agric-Land

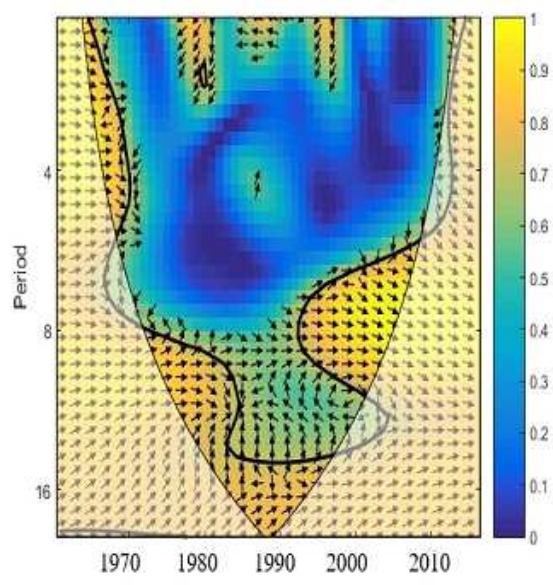

c: WTC between TFP \& $\mathrm{CO}_{2}$

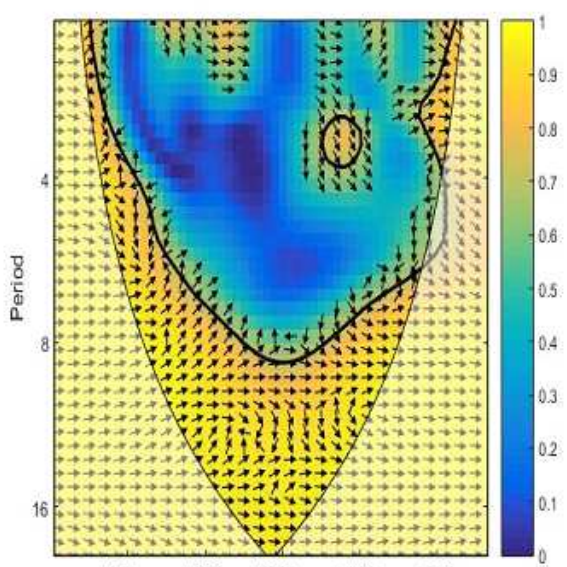

$\begin{array}{lllll}1970 & 1980 & 1990 & 2000 & 2010\end{array}$

d. WTC Between TFP \& Feed

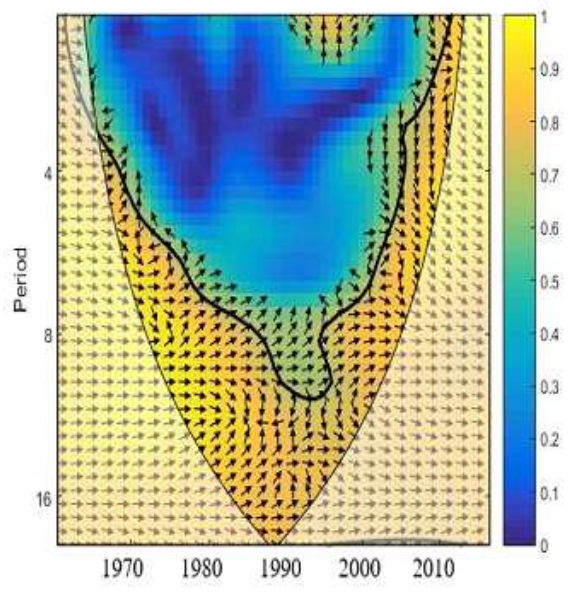

e:WTC Between TFP \& Fertilizer

Figure 4

a: WTC Between TFP \& AgricLabor b: WTC Between TFP \& Agric-Land c: WTC between TFP \& CO2 d: WTC Between TFP \& Feed e WTC Between TFP \& Fertilizer

\section{Supplementary Files}


This is a list of supplementary files associated with this preprint. Click to download.

- S1.xlsx 